\title{
Checklist of mammals from Mato Grosso do Sul, Brazil
}

\author{
Walfrido Moraes Tomas ${ }^{1,4}$, Pâmela Castro Antunes, 1,4 , Marcelo Oscar Bordignon 2,4, André Restel \\ Camilo ${ }^{3}$, Zilca Campos ${ }^{1}$, George Camargo ${ }^{4}$, Luiz Felipe Alves da Cunha Carvalho ${ }^{4}$, Nicolay Leme da \\ Cunha ${ }^{4}$, Erich Fischer ${ }^{2,4}$, Mauricio Neves Godoi ${ }^{4}$, Wellington Hannibal ${ }^{4,5}$, Guilherme Mourão ${ }^{1,4}$, José \\ Rimoli 6,7 , Carolina Ferreira Santos ${ }^{3}$, Mauricio Silveira ${ }^{4}$ \& Marcelle Aiza Tomas ${ }^{8}$
}

\footnotetext{
1. Laboratório de Vida Selvagem, Embrapa Pantanal, Rua 21 de Setembro, 1880, 79320-900 Corumbá, MS, Brasil. (walfrido.tomas@embrapa.br)

2. Centro de Ciências Biológicas e da Saúde, Universidade Federal de Mato Grosso do Sul, 79070-900 Campo Grande, Mato Grosso do Sul, Brasil.

3. Bolsista Fundect/Embrapa Pantanal. Laboratório de Vida Selvagem, Embrapa Pantanal, Rua 21 de Setembro, 1880, 79320-900 Corumbá, MS, Brasil.

4. Programa de Pós-Graduação em Ecologia e Conservação, Centro de Ciências Biológicas e da Saúde, Universidade Federal de Mato Grosso do Sul,

Cidade Universitária s/n, Caixa Postal 549, 79070-900 Campo Grande, MS, Brasil.

5. Laboratório de Ecologia e Biogeografia de Mamíferos, Universidade Estadual de Goiás, Av. Brasil, Q.03, L.01, 75860-000 Quirinópolis, GO, Brasil.

6. Universidade Federal de Mato Grosso do Sul, Campus de Aquidauana (CPAq), Rua Oscar Trindade de Barros, 749, $79200-000$ Aquidauana, MS, Brasil.

7. Programa de Pós-Graduação em Biologia Animal, Centro de Ciências Biológicas e da Saúde, Universidade Federal de Mato Grosso do Sul,

Cidade Universitária s/n, Caixa Postal 549, 79070-900, Campo Grande, MS, Brasil.

8. Bolsista Biota-MS/Embrapa Pantanal, Laboratório de Vida Selvagem, Embrapa Pantanal, Rua 21 de Setembro, 1880, 79320-900, Corumbá, MS, Brasil.
}

Received 21 November 2016

Accepted 6 February 2017

DOI: $10.1590 / 1678-4766 e 2017155$

\begin{abstract}
We updated the checklist of mammals from Mato Grosso do Sul, Brazil based on primary records only. One hundred and sixty-six mammal species were listed as occurring in the state, 47 of them being medium to large, 47 small mammal and 73 bat species. The listed species are distributed in 31 families: Didelphidae (17 spp.), Dasypodidae (7 spp.), Myrmecophagidae (2 spp.), Cebidae (1 sp.), Callithrichidae (2 spp.), Aotidae (1 sp.), Pitheciidae (1 sp.), Atelidae (1 sp.), Leporidae (1 sp.), Felidae (7 spp.), Canidae (4 spp.), Mustelidae (5 spp.), Mephitidae (2 spp.), Procyonidae (2 spp.), Tapiridae (1 sp.), Tayassuidae (2 spp.), Cervidae (4 spp.), Sciuridae (1 sp.), Cricetidae (22 spp.), Erethizontidae (1 sp.), Caviidae (3 spp.), Dasyproctidae (1 sp.), Cuniculidae (1 sp.), Echimyidae (4 spp.), Phyllostomidae (41 spp.), Emballonuridae (2 spp.), Molossidae (16 spp.), Vespertilionidae (9 spp.), Mormoopidae (1 sp.), Noctilionidae (2 spp.), and Natalidade (1 sp.). These numbers represent an increase of fourteen species with primary records for the state in comparison with the previously published checklist. However, it is evident the scarcity of information at several regions of the state, and the need of implementation of regional zoological collections. The state of Mato Grosso do Sul represent only $4.19 \%$ of the Brazilian territory, but the number of mammal species reach $24.13 \%$ of the known species occurring in the country.
\end{abstract}

KEYWORDS. Mammals, Mato Grosso do Sul, checklist, Biota-MS Program.

RESUMO. Lista de mamíferos do Mato Grosso do Sul, Brasil. Atualizamos a lista de mamíferos do estado de Mato Grosso do Sul, Brasil com base em registros primários. Cento e sessenta e seis espécies são listadas como ocorrentes no estado, sendo 47 de mamíferos de médio e grande porte, 46 de pequenos mamíferos e 73 de morcegos. As espécies listadas estão distribuídas em 31 famílias: Didelphidae (17 spp.), Dasypodidae (7 spp.), Myrmecophagidae (2 spp.), Cebidae (1 sp.), Callithrichidae (2 spp.), Aotidae (1 sp.), Pitheciidae (1 sp.), Atelidae (1 sp.), Leporidae (1 sp.), Felidae (7 spp.), Canidae (4 spp.), Mustelidae (5 spp.), Mephitidae (2 sp.), Procyonidae (2 spp.), Tapiridae (1 sp.), Tayassuidae (2 spp.), Cervidae (4 spp.), Sciuridae (1 sp.), Cricetidae (22 spp.), Erethizontidae (1 sp.), Caviidae (3 spp.), Dasyproctidae (1 sp.), Cuniculidae (1 sp.), Echimyidae (4 spp.), Phyllostomidae (41 spp.), Emballonuridae (2 spp.), Molossidae (16 spp.), Vespertilionidae (9 spp.), Mormoopidae (1 sp.), Noctilionidae (2 spp) e Natalidade (1 sp.). Estes números representam um aumento de quatorze espécies com registro primário para o estado em comparação com a listagem publicada anteriormente. Ainda assim, é evidente a escassez de informações em diversas regiões do estado, e a necessidade de implementação de coleções zoológicas regionais. O estado de Mato Grosso do Sul representa apenas 4,19\% do território brasileiro, mas o número de mamíferos atinge 24,13\% do total de espécies que ocorrem no país.

PALAVRAS-CHAVE. Mamíferos, Mato Grosso do Sul, Lista, Programa Biota-MS.

The mammalian fauna from Mato Grosso do Sul state of Brazil was first compiled by CÁCERES et al. (2008), but checklists have been published for specific regions in the state, such as the Acurizal ranch, in the Amolar mountain range (SCHALler, 1983; Tomas \& MourÃo, 2007), the Nhumirim ranch, in the Nhecolândia region of the Pantanal (ALHO et al., 1987), the Bodoquena mountain range (CÁCERES et al., 2007b; CAMARgo et al., 2009), Serra de Maracaju (HANNIBAL \& Godoy, 2015), and the Urucum mountains, near Corumbá (Bordignon \& FranÇA, 2009; Godor et al., 2010a; CÁCERES et al., 2011). Additional publications report the distribution of isolated species or group of species, often not comprehending solely the Mato Grosso do Sul territory (e.g., Carmignotto, 2004; Carmignotto \& Monfort, 2006; CÁCERES et al., 2006, 2007b; SANTOS et al., 2010; Godor et al., 2010b; SilveIRA et al., 2011; HanNiBAL et al., 2012; TERIBELE et al., 2012).

Collections of zoological material have been conducted in Mato Grosso do Sul since 1817 by naturalist expeditions crossing the western region of Brazil, with 
specimens usually deposited in several overseas and national museums. J. Natterer, for example, visited the western region of the modern state of Mato Grosso do Sul from 1824 to 1830 (Pelzen, 1883; Vanzolini, 1993); H. H. Smith travelled through the state up to Cuiabá, in the modern state of Mato Grosso, navigating along the Paraguay river in 1882 and 1886 (Cope, 1889; ALLEN, 1891, 1892, 1893); many mammal records and specimens were obtained during the construction of telegraph lines by Marechal Cândido M. S. Rondon, crossing also many parts of the sate (MIRANDA RIBEIRO, 1914), and by the Roosevelt-Rondon Expedition, which crossed the Pantanal region from 1913 to 1914 (MILLER, 1915). The Instituto Oswaldo Cruz, conducted expeditions to the Cuiabá and São Lourenço rivers in 1922, which separate Mato Grosso from Mato Grosso do Sul states (Travassos et al., 1927). Collections of zoological material were also conducted in Salobra region, Mato Grosso do Sul, along the Noroeste do Brasil railway (e.g., VIEIRA, 1940, 1955; Travassos, 1940). These expeditions provided relevant scientific material that become the basis for many published mammal checklists for Brazil (e.g, VIEIRA, 1955) and are still supporting regional analysis of the vertebrate fauna in the western region of the country.

Since then, little effort has been applied to establish regional zoological collections, as well as to conduct sound inventories in most of the state. Two comprehensive inventories were conducted more than 30 years ago, both in the Pantanal wetland (SCHALler, 1983; AlHo et al., 1987). Recently, some inventories have been conducted in Mato Grosso do Sul, such as those in the Aporé and Sucuriú river basins, in the northeastern region of the state (BORDIGNON et al., 2006), in the Bodoquena mountain range, in the southwestern region of the state (CÁCERES et al., 2007a), in the Pousada Araraúna, located in the southeastern region of the Pantanal (MAMEde \& AlHo, 2006), in the northwestern region (PulchÉRIO-Leite et al., 1998; AlHo et al., 2011), at the Serra do Amolar (Tomas \& MourÃo, 2007), Serra de Maracaju (Hannibal \& Godoy, 2015) and in the Urucum mountains near Corumbá (GoDor et al., 2010a; CÁCERES et al., 2011). However, these inventories do not include all taxonomic groups among mammals. Additional publications are restricted to species distribution, such as Tomas et al. (2009).

This article aims to update the checklist of mammal species from Mato Grosso do Sul in the light of recent data, especially those based on museum specimens and geo-referenced photographs and videos cataloged in image collections. As a result, the present checklist should be considered conservative, as non-primary records were excluded. We also intend to point out taxonomic inconsistencies that should be subjected to more detailed studies concerning taxonomy and species distribution.

\section{MATERIAL AND METHODS}

The list of mammal species (Tab. I) is based only on primary records. Specimens deposited at regional and national collections were obtained directly from specimens examination and from recent publications that listed vouchers used to report species occurrence, taxonomic reviews, and species distributions. Given the difficulties in accessing important mammal collections at relevant national and international museums, especially those that do not offer online information on the specimens, we consider this list as a basic checklist. Overall taxonomic nomenclature follows PAGLIa et al. (2012), which incorporates WILSON \& REEDER (2005). Recent modifications were used, such as LIM et al. (2004) for Artibeus planirostris, WEKSLER et al. (2006) for the genera Cerradomys, Euryoryzomys and Hyaleamys, LynCH Alfaro et al. (2011) for Cebus, GARBINO \& TEJEDOR (2012) for Natalus macrourus, and NASCIMENTO et al. (2013) for Thrichomys. The specimens and image records considered in this article are listed in the Table III. To avoid an inflated list of species, we did not include in the present checklist undetermined or not yet described species (reported as Genus). Taxonomic entities described as "group" were not considered, as the authors who published them stated that this treatment was adopted due to the impossibility to precisely identify the voucher species with cariotipying as not suitable samples are available. Data from and reports based on interviews were avoided. Pictures of signs (tracks, burrows and other evidence) were included only if they permit unmistakably identification of the species. All taxa were considered up to the species level, not considering sub-species. Non-native species were not included.

\section{RESULTS AND DISCUSSION}

One hundred and sixty-six mammal species were listed as occurring in the Mato Grosso do Sul state, Brazil, 47 of them being medium to large, 46 small mammal and 73 bat species. These numbers represent an increase of fourteen species to the previous publication (CÁCERES et al., 2008), considering that we did not account for undefined species cited as Genus, or group of species, or species with no primary records. The mammal species confirmed to the state are distributed in 31 Families: Didelphidae (17 spp.), Dasypodidae (7 spp.), Myrmecophagidae (2 spp.), Cebidae (1 sp.), Callithrichidae (2 spp.), Aotidae (1 sp.), Pitheciidae (1 sp.), Atelidae (1 sp.), Leporidae (1 sp.), Felidae (7 spp.), Canidae (4 spp.), Mustelidae (5 spp.), Mephitidae (2 sp.), Procyonidae (2 spp.), Tapiridae (1 sp.), Tayassuidae (2 spp.), Cervidae (4 spp.), Sciuridae (1 sp.), Cricetidae (22 spp.), Erethizontidae (1 sp.), Caviidae (3 spp.), Dasyproctidae (1 sp.), Cuniculidae (1 sp.), Echimyidae (4 spp.), Phyllostomidae (41 spp.), Emballonuridae (2 spp.), Molossidae (17 spp.), Vespertilionidae (9 spp.), Mormoopidae (1 sp.), Noctilionidae (2 spp.) and Natalidade (1 sp.). However, these numbers should be considered not definitive, as sound inventories are still rare in several regions of the state. As an example, in the Southern Cone (south of the Ivinhema river basin), once covered by the Atlantic Forest, little is known about the mammal fauna, and only one checklist for this region has been published (HANNIBAL, 2014). We estimate that 
Tab. I. Checklist of mammal species from Mato Grosso do Sul state, Brazil.

\begin{tabular}{cl}
\hline ORDER & \\
FAMILY & Species \\
\hline DIDELPHIMORPHIA & \\
DIDELPHIDAE & Caluromys lanatus (Olfers, 1818) \\
Caluromys philander Linnaeus, 1758 \\
Chironectes minimus (Zimmermann, 1780) \\
Cryptonanus agricolai (Moojen, 1943) \\
Cryptonanus chacoensis (Tate, 1931) \\
Didelphis albiventris Lund, 1840 \\
Didelphis aurita (Wied-Neuwied, 1826) \\
Didelphis marsupialis Linnaeus, 1758 \\
Gracilinanus agilis (Burmeister, 1854) \\
Lutreolina crassicaudata (Desmarest, 1804) \\
Marmosa (Micoureus) constantiae (Thomas, 1904) \\
Marmosa murina Linnaeus, 1758 \\
Marmosops ocellatus (Tate, 1931) \\
Monodelphis domestica (Wagner, 1842) \\
Monodelphis kunsi Pine, 1975 \\
Phillander opossum (Linnaeus, 1758) \\
Thylamys macrurus (Olfers, 1818)
\end{tabular}

CINGULATA

Dasypus novemcinctus Linnaeus, 1758

Dasypus semptemcinctus Linnaeus, 1758

Euphractus sexcinctus (Linnaeus, 1758)

Priodontes maximus (Kerr, 1792)

Tolypeutes matacus (Desmarest, 1804)

Cabassous unicinctus (Linnaeus, 1758)

PILOSA

MYRMECOPHAGIDAE

PRIMATES

CEBIDAE

CALLITHRICHIDAE

AOTIDAE

PITHECIIDAE

ATELIDAE

LAGOMORPHA

LEPORIDAE

\section{CARNIVORA}

FELIDAE

CANIDAE

Myrmecophaga tridactyla Linnaeus, 1758

Tamandua tetradactyla (Linnaeus, 1758)

Sapajus cay (Illiger, 1815)

Mico melanurus (É. Geoffroy, 1812)

Callithrix penicillata (É. Geoffroy, 1812)

Aotus azarae (Humboldt, 1812)

Callicebus cf. pallescens Thomas, 1907

Alouatta caraya (Humboldt, 1812)

Sylvilagus brasiliensis (Linnaeus, 1758)

Leopardus colocolo (Molina, 1782)

Leopardus pardalis (Linnaeus, 1758)

Leopardus guttulus (Schreber, 1775)

Leopardus wiedii (Schinz, 1821)

Puma concolor (Linnaeus, 1771)

Puma yagouaroundi (É. Geoffroy, 1803)

Panthera onca (Linnaeus, 1758)

Cerdocyon thous (Linnaeus, 1766)

Chrysocyon brachyurus (Illiger, 1815)

Lycalopex vetulus (Lund, 1842)

Speothos venaticus (Lund, 1842)

MUSTELIDAE

Lontra longicaudis (Olfers, 1818)

Pteronura brasiliensis (Gmelin, 1788)

Eira barbara (Linnaeus, 1758) 
Tab. I. Cont.

\begin{tabular}{|c|c|}
\hline ORDER & \\
\hline FAMILY & Species \\
\hline & Galictis cuja (Molina, 1782) \\
\hline & Galictis vitatta (Scheber, 1776) \\
\hline MEPHITIDA & \\
\hline & Conepatus semistriatus (Boddaert, 1785) \\
\hline & Conepatus chinga (Molina, 1782) \\
\hline PROCYONI & \\
\hline & Nasua nasua (Linnaeus, 1766) \\
\hline & Procyon cancrivorus (G. Cuvier, 1798) \\
\hline PERISSODACT & \\
\hline TAPIRIDAE & \\
\hline & Tapirus terrestris (Linnaeus, 1758) \\
\hline ARTIODACTY & \\
\hline TAYASSUII & \\
\hline & Pecari tajacu (Linnaeus, 1758) \\
\hline & Tayassu pecari (Link, 1795) \\
\hline CERVIDAE & \\
\hline & Blastocerus dichotomus (Illiger, 1815) \\
\hline & Mazama americana (Erxleben, 1777) \\
\hline & Mazama gouazoubira (Fischer, 1814) \\
\hline & Ozotoceros bezoarticus (Linnaeus, 1758) \\
\hline RODENTIA & \\
\hline SCIURIDAI & \\
\hline & Urosciurus spadiceus (Olfers, 1818) \\
\hline CRICETID & \\
\hline & Akodon montensis Thomas, 1913 \\
\hline & Akodon toba Thomas, 1921 \\
\hline & Calomys aff. callidus (Thomas, 1916) \\
\hline & Calomys callosus (Rengger, 1830) \\
\hline & Cerradomys maracajuensis (Langguth \& Bonvicino, 2002) \\
\hline & Cerradomys scotti (Langguth \& Bonvicino, 2002) \\
\hline & Euryoryzomys nitidus (Thomas, 1884) \\
\hline & Holochilus chacarius Wagner, 1842 \\
\hline & Hylaeamys megacephalus (Fischer, 1814) \\
\hline & Necromys lasiurus (Lund 1841) \\
\hline & Nectomys rattus (Pelzeln, 1883) \\
\hline & Nectomys squamipes (Brants, 1827) \\
\hline & Oecomys bicolor (Thomas, 1860) \\
\hline & Oecomys catherinae Thomas, 1909 \\
\hline & Oecomys mamorae (Thomas, 1906) \\
\hline & Oecomys paricola (Thomas, 1904) \\
\hline & Oligoryzomys chacoensis (Myers \& Carleton, 1981) \\
\hline & Oligoryzomys fornesi (Massoia, 1973) \\
\hline & Oligoryzomys nigripes (Olfers, 1818) \\
\hline & Oxymycterus delator Thomas, 1903 \\
\hline & Pseudoryzomys simplex (Winge, 1887) \\
\hline & Rhipidomys macrurus (Gervais, 1855) \\
\hline ERETHIZO & \\
\hline & Coendou prehensilis (Linnaeus, 1758) \\
\hline CAVIIDAE & \\
\hline & Cavia aperea Erxleben, 1777 \\
\hline & Cavia fulgida Wagler, 1831 \\
\hline & Hydrochoerus hydrochaeris (Linnaeus, 1766) \\
\hline DASYPROC & \\
\hline & Dasyprocta azarae Lichtenstein, 1823 \\
\hline CUNICULII & \\
\hline & Cuniculus paca (Linnaeus, 1766) \\
\hline ECHIMYID & \\
\hline & Clyomys laticeps (Thomas, 1909) \\
\hline & Proechimys longicaudatus (Rengger, 1830) \\
\hline & Proechimys roberti Thomas, 1901 \\
\hline & Thrichomys fosteri (Thomas, 1903) \\
\hline CHIROPTERA & \\
\hline PHYLLOST & \\
\hline & Lophostoma brasilienses Peters, 1866 \\
\hline & Lophostoma silvicolum d'Orbigny, 1836 \\
\hline
\end{tabular}


Tab. I. Cont.

\begin{tabular}{|c|c|}
\hline ORDER & \\
\hline FAMILY & Species \\
\hline & Macrophyllum macrophyllum (Schinz, 1821) \\
\hline & Micronycteris sanborni Simmons, 1996 \\
\hline & Micronycteris minuta (Gervais, 1856) \\
\hline & Micronycteris megalotis Gray, 1842 \\
\hline & Chrotopterus auritus (Peters, 1856) \\
\hline & Lonchorhina aurita Tomes 1863 \\
\hline & Mimon bennettii (Gray, 1838) \\
\hline & Mimon crenulatum (E. Geoffroy, 1803) \\
\hline & Phylloderma stenops Peters, 1865 \\
\hline & Phyllostomus elongatus (E. Geoffroy, 1810) \\
\hline & Phyllostomus hastatus (Pallas, 1767) \\
\hline & Phyllostomus discolor Wagner, 1843 \\
\hline & Tonatia bidens (Spix, 1823) \\
\hline & Trachops cirrhosus (Spix, 1823) \\
\hline & Vampyrum spectrum (Linnaeus, 1758) \\
\hline & Artibeus cinereus (Gervais, 1856) \\
\hline & Artibeus fimbriatus Gray, 1838 \\
\hline & Artibeus planirostris (Spix, 1823) \\
\hline & Artibeus obscurus (Schinz, 1821) \\
\hline & Artibeus lituratus (Olferns, 1818) \\
\hline & Chiroderma villosum Peters, 1860 \\
\hline & Chiroderma doriae O. Thomas, 1891 \\
\hline & Platyrrhinus helleri (Peters, 1866) \\
\hline & Platyrrhinus lineatus (E. Geoffroy, 1810) \\
\hline & Pygoderma bilabiatum (Peters, 1863) \\
\hline & Uroderma bilobatum Peters, 1866 \\
\hline & Uroderma magnirostrum Davis, 1868 \\
\hline & Vampyressa pusilla (Wagner, 1843) \\
\hline & Vampyrodes caraccioli (Thomas, 1889) \\
\hline & Sturnira lilium (E. Geoffroy, 1810) \\
\hline & Desmodus rotundus (E. Geoffroy, 1810) \\
\hline & Diaemus youngi (Jentink, 1843) \\
\hline & Anoura geoffroyi Gray, 1838 \\
\hline & Anoura caudifer (E. Geoffroy, 1818) \\
\hline & Glossophaga soricina (Pallas, 1766) \\
\hline & Lonchophylla dekeyseri Taddei, Vizotto \& Sazima, 1983 \\
\hline & Lonchophylla mordax (Thomas, 1903) \\
\hline & Lionycteris spurrelli (Thomas, 1913) \\
\hline & Carollia perspicillata (Linnaeus, 1758) \\
\hline EMBALLON & \\
\hline & Peropteryx macrotis (Wagner, 1843) \\
\hline & Rhynchonycteris naso (Wied-Neuwied, 1820) \\
\hline MOLOSSID & \\
\hline & Cynomops abrasus (Temminck, 1827) \\
\hline & Cynomops planirostris (Peters, 1865) \\
\hline & Eumops bonariensis (Peters, 1874) \\
\hline & Eumops dabbenei Thomas 1914 \\
\hline & Eumops glaucinus (Wagner, 1843) \\
\hline & Eumops patagonicus Thomas, 1924 \\
\hline & Eumops perotis (Schinz, 1821) \\
\hline & Eumops auripendulus (Shaw, 1800) \\
\hline & Molossops temminckii (Burmeister, 1854) \\
\hline & Molossus rufus (E. Geoffroy, 1805) \\
\hline & Molossus molossus (Pallas, 1856) \\
\hline & Molossus pretiosus (Miller, 1902) \\
\hline & Nyctinomops macrotis (Gray, 1840) \\
\hline & Nyctinomops laticaudatus (E. Geoffroy, 1805) \\
\hline & Promops centralis Thomas, 1915 \\
\hline & Promops nasutus (Spix, 1823) \\
\hline & Tadarida brasiliensis (I. Geoffroy, 1824) \\
\hline VESPERTIL & \\
\hline & Eptesicus furinalis (d’Orbigny, 1847) \\
\hline & Eptesicus brasiliensis (Desmarest, 1819) \\
\hline & Lasiurus blossevillii (Lesson \& Garnot, 1826) \\
\hline & Lasiurus cinereus (Beauvois, 1796) \\
\hline
\end{tabular}


Tab. I. Cont.

\begin{tabular}{cl}
\hline ORDER & Species \\
FAMILY & Lasiurus ega (Gervais, 1856) \\
& Myotis nigricans (Schinz, 1821) \\
& Myotis simus Thomas, 1901 \\
& Myotis riparius Handley, 1960 \\
& Myotis albescens (E. Geoffroy, 1806) \\
MORMOOPIDAE & Pteronotus parnellii (Gray, 1840) \\
NOCTILIONIDAE & Noctilio albiventris (Desmarest, 1818) \\
& Noctilio leporinus (Linneaus, 1758) \\
NATALIDAE & Natalus macrourus (Gervais, 1856) \\
\hline
\end{tabular}

about 14 species may be included in future checklists as additional inventories and taxonomic studies are developed. To date, there is no evidence of any endemic mammal species occurring in the state.

The total number of mammal species in the world is nearly 5,490 (IUCN, 2012), while the estimated number of bat species is 1,100 (JAN et al., 2012), resulting in 4,390 non-flying mammal species. In comparison, the number of mammal species in Brazil has been estimated as 688 (REIS et al., 2011), including bats and cetaceans. The Mato Grosso do Sul state comprises only $4.19 \%$ of the Brazilian Territory $\left(357,125 \mathrm{~km}^{2}\right.$ and $8,515,767 \mathrm{~km}^{2}$, respectively), but the number of species in the state represent $24.13 \%$ of the known mammalian fauna for the entire country. The number of non-flying mammal species in the Mato Grosso do Sul fits well in an expected species-area relationship curve (Fig. 1), which includes data from Brazil, Okavango Delta (RAMBERG et al., 2006), Amazon Rainforest, Atlantic Forest, Caatinga, Cerrado, Chaco, Llanos from Venezuela and Colombia (OJasti, 1990), Congo Rainforest, Borneo Rainforest, Guinean Rainforest (see Tomas et al., 2011; MYers et al., 2000), Paraguay (YAHNke et al., 1998), the São Paulo State (DE VIVo et al., 2011), and Brazil as a whole (REIS et al., 2011).

The present list of species reveals a necessity of better taxonomic evaluation for specific taxa. One example is the Callicebus from the western limit of the Pantanal wetland, in the border with Bolivia. The species recognized as occurring in this region is Callicebus pallescens (Groves, 2001; ROOSMALEN et al., 2002), despite several publications since HershKovitz (1990), including the last review of the Genus (RoOsmalen et al., 2002), place the species as occurring inside the Pantanal wetland. In reality, within Mato Grosso do Sul State, Callicebus is restricted to the mountainous region near Corumbá and in the Serra do Amolar range (Tomas et al., 2011). The taxonomic identity of these Callicebus populations are still confuse, since both phenotypic traits, such as coat color patterns (Tomas et al., 2011), and molecular genetic data (AURICCHIO, 2005) indicate that individuals from Corumbá are distinguishable from both C. pallescens and C. donacophilus. The northern populations from the Serra do Amolar region resemble $C$. donacophilus (Tomas et al., 2011), while the southern population seems to differ from both valid species ( $C$. pallescens and $C$. donacophilus). Thus, it is possible that the populations from Corumbá will correspond to a separated species, requiring more detailed taxonomic studies based on molecular genetics at finer geographic detail. Among primates, Sapajus seems to be represented by two species, considering the presumable occurrence of Sapajus libidinosus in the northeastern portion of the state. This species is well known to occur at Emas National Park and it is distributed along a diagonal gradient from northeastern to central Brazil (LYNCH ALFARO et al., 2011; CÁCERES et al., 2015). There is no reason for its absence in the northeastern region of the Mato Grosso do Sul, as a portion of the Emas National Park is within the state.

Among carnivores, relatively common species are still little known regarding occurrence and taxonomic identity. The lack of museum specimens difficults the analysis on the occurrence and distribution of Conepatus and Galictis.

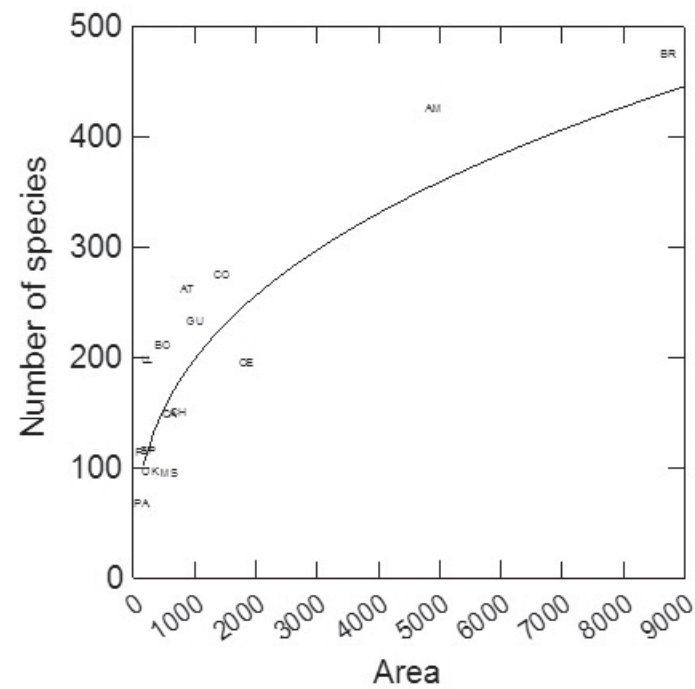

Fig. 1. Species-area relationship for the number of non-flying mammal species from several tropical ecosystems and regions/countries (modified from Tomas et al., 2011). The fitted model is: Number of species $=$ $11.78^{*}$ AREA $^{0.41}$; Mean corrected R ${ }^{2}(1$-residual $/$ corrected $)=0.88$; Regions: $\mathrm{AM}$, Amazon rainforest; AR, Argentina; AT, Atlantic rainforest; $\mathrm{BO}$, Borneo rainforest; $\mathrm{BR}$, Brazil; $\mathrm{CA}$, Caatinga; $\mathrm{CE}$, Cerrado; $\mathrm{CH}$, Chaco; $\mathrm{CO}$, Congo rainforest; GU, Guinean rainforest; LL, Llanos; MS, Mato Grosso do Sul state (this checklist); OK, Okavango delta; PA, Pantanal wetland; PY, Paraguay; SP, São Paulo state. 
Rare records have been published on Conepatus, but we present evidence of two species occurring in the state. Conepatus semistriatus occurs at Emas National Park (RoDrigues et al., 2002), part of which is located in Mato Grosso do Sul, and we present a photographic record of this species in the northeastern region of Mato Grosso do Sul (MCPAPI 515). The dimensions of several tracks documented in the Pantanal wetland suggest $C$. semistriatus in the floodplains, but this evidence is not sufficient to confirm the species there. Another species of this genus, Conepatus chinga have been reported from Maracaju municipality (AMNH 133946), in the central-southern region of the state (DrAGOo et al., 2003). Based on these evidences, we included the two species in our checklist. YENSEN \& TARIFA (2003a) report the occurrence of Galictis vitatta for the state, but we found no museum specimen to document it. We included this species in our list based on photograph documentation from Pantanal, which is placed in the mammal reference collection at Embrapa Pantanal (MCPAPI 501). The occurrence of $G$. cuja follows the same situation (YENSEN \& TARIFA, 2003b), and we have included this species in our list based on two photographic records placed in the Embrapa's reference collection (MCPAPI 5008, 516). Among cats, we found no evidence of $L$. geofroyii in the state despite distribution maps often include this species in the southwestern region (e.g., Cheida \& SAntos, 2010).

After the review by TRIGO et al.(2013), we considered Leopardus guttulus as the species valid for Mato Grosso do Sul, instead of L. tigrinus, cited by other authors before(e.g., CÁCERES et al., 2008). TRIGo et al. (2013) used in their analysis one sample collected from one individual originated from Miranda-MS, and kept in a Zoo at Catanduva, São Paulo state (bLti-072, deposited in the Banco de Amostras from the Laboratório de Biologia Genômica e Molecular, from the Universidade Federal do Rio Grande do Sul; this individual is identified as the number 017 in the Plano de Manejo de Pequenos Felinos Brasileiros). Thus, in the Tables II and III, all the specimens formerly considered as L. tigrinus will be considered as L. guttulus, despite additional genetic analysis is still required to clarify this issue.

We found in the Order Cingulata that Cabassous chacoensis has no confirmed records in Brazil, although it occurs in the Chaco region of Paraguay and Bolivia (WETZEL, 1980). One C. chacoensis specimen has been labeled as "from Brazil", but no further information is available about the locality of its collection (WeTzeL, 1980). Thus, the species has not been included in our list, even considering that the southwestern region of the state is in close contact with the Chaco, and presents typical Chacoan vegetation along the border with Paraguay in the Porto Murtinho municipality.

Among small mammals, we excluded Akodon gr. cursor reported by CARMIGNOTTO (2004), and also Proechimys gr. goeldii and Oecomys gr. catherinae listed by CARMignotTo (2004) and CÁCERES et al. (2008), as we adopted a conservative approach to construct the present checklist. Following the same approach, we did not include in our checklist Rhipidomys sp., listed by CARMignOTTO (2004), and Akodon sp. and Callomys sp., listed by CARMignotTo (2004) and CÁCERES et al. (2008) respectively (see Tables III and IV). Among potential species to be occurring in the state, we speculate that in the northeastern region of Mato Grosso do Sul it is possible to find Thylamys velutinus, Calomys expulsus and Carterodon sulcidens. These species do occur in the nearby region contiguous to the state of Goiás, where there are no evident geographic barriers, which would limit dispersion between both states (e.g., large rivers). Micoureus paraguayanus and Phillander frenatus may also occur in the southernmost part of the state, once covered by the Atlantic forest, as these species are known to occur in the adjacent eastern regions of Paraguay. The occurrence of Metachirus nudicaudatus was reported by GARDNER \& DAgosto (2008) in the Urucum Mountains, near Corumbá, and in the Dourados municipality. However, the authors did not provide information about voucher specimens. Thus, this species was not included in our checklist. A probable new species of Dasyprocta may occurs in the Serra do Amolar region (IACK-XIMENEZ, 1999), but we did not include it in the present checklist, as it is still not formally described. As for bats, COELHO (2005) reported Rhinophylla pumilio for the northern region of the state, however without a voucher specimen.

The specimens from Mato Grosso do Sul considered by CÁCEREs et al. (2008) and CARMINGNOTO (2004) as Holochilus sciureus are still in need of analysis to clarify if they actually correspond to $H$. chacarius, as the presence of the former species in the state have been questioned by BRANDÃO \& NASCIMENTO (2015). These specimens originated in the state and deposited elsewhere are AMNH 37077, FMNH 26758-2678, USNM 390249-39050, MN 1989-42074209- 4205-4271, AMNH 37077, MN 1987, MZUSP $3780-$ 27430, UFSM 266, USNM 390249, and those deposited as MCPAP 217-218-221-223 (see Table III for the institution names). The consistence of $H$. chacarius occurring in the state is indicated in the recent publication by D'ELÍA et al.(2015), based on molecular analysis.

At least four exotic species are known to occur in the Mato Grosso do Sul as feral populations. The feral pig, Sus scrofa, also known as "porco monteiro", has been introduced by the first settlers two centuries ago, and is presently abundant in the Pantanal wetland. The wild hog, also Sus scrofa, is invading several regions of the state after releases from captivity few years ago, and is about to become a nuisance in the central and southern areas of the state. The European hare, Lepus europaeus, have been reported for the Bodoquena mountains (CÁCERES et al., 2007a), despite no primary records are available to the present. Rattus rattus has been reported by CÁCERES et al. (2007a). Finally, relatively small populations of feral water buffaloes Bubalus bubalis scattered in the Pantanal floodplains (Mourão et al., 2002).

Twelve mammal species listed by the Brazilian government as threatened do occur in the Mato Grosso do Sul state, all of them classified as Vunerable: nine for Carnivora, one for Artiodactyla, one for Cingulata, and one for Pilosa. The IUCN Red List included 17 globally 
Tab. II. Threatened mammals species listed by Brazilian government (MinisTÉRIo do MeIo AMBIENTE, 2014) and International Union for Conservation of Nature (IUCN) occurring in the state of Mato Grosso, Brazil (Categories: NT, Near Threatened; VU, Vulnerable; EN, Endangered).

\begin{tabular}{lccc}
\hline Species & Common name & Brazil & IUCN \\
\hline Blastocerus dichotomus & Marsh deer & VU & NT \\
Chrysocyon brachyurus & Manned wolf & VU & NT \\
Leopardus colocolo & Pampas cat & VU & VU \\
Leopardus pardalis & Ocelot & VU & NT \\
Leopardus guttulus & Oncilla & EN & NT \\
Leopardus wiedii & Magay & VU & \\
Lonchophylla dekeyseri & Dekeyser's nectar bat & EN & \\
Lonchorhina aurita & Tome's sword-nosed bat & VU & \\
Lycalopex vetulus & Hoary fox & VU & \\
Myrmecophada tridactyla & Giant anteater & VU & \\
Natalus macrourus & Brazilian funnel-eared bat & VU & NT \\
Ozotoceros bezoarticus & Pampas deer & VU & NT \\
Panthera onca & Jaguar & VU & VU \\
Priodontes maximus & Giant armadillo & VU & EN \\
Pteronura brasiliensis & Giant otter & VU & \\
Puma concolor & Puma & VU & \\
Puma yagouarondi & Weasel cat & VU & \\
Sapajus cay & Capuchin monkey & VU & \\
Speothos venaticus & Bush dog & VU & \\
Tapirus terrestris & Tapir & VU & NT \\
Tayassu pecari & Whylamys macrurus & VU & VU \\
Tolypeutes matacus & EN & VU \\
Vampyrum spectrum & Paraguayan fat-tailed mouse possum & NT \\
\hline
\end{tabular}

Tab. III. Specimens considered in the elaboration of the checklist of non-flying mammals of the Mato Grosso do Sul state, Brazil. The specimens examined by other authors are followed by the reference to the correspondent publication. The taxons follow an alphabetical order, independent of their higher level taxonomic classification (Subfamily, Family, Order). The collections included are: MCPAP, Coleção de Referência de Mamíferos da Embrapa Pantanal; MCPAPI, Coleção de Imagens de Referência de Mamíferos da Embrapa Pantanal; MN, Museu Nacional; MZUSP, Museu de Zoologia da Universidade de São Paulo; UFSM, Coleção de Mamíferos da Universidade Federal de Santa Maria; AMNH, American Museum of Natural History; CEUCM, Centro Universitário de Corumbá - Coleção de Mamíferos; FMNH, Field Museum of Natural History; MHNCI, Museu de História Natural Capão da Imbuia; OMNH, Oklahoma Museum of Natural History; UEMS, Universidade Estadual do Mato Grosso do Sul; UFMG, Universidade Federal de Minas Gerais; UFSC, Universidade Federal de Santa Catarina; USNM, National Museum of Natural History; JLP, James L. Patton (voucher at UFMG mammal collection, as cited by WeKsLER, 2003); CRB (Cibele R. Bonvicino); LBCE (Laboratório de Biologia e Parasitologia de Mamíferos Reservatórios silvestres, Fiocruz); MVZ (Museum of Vertebrate Zoology, University of California, Bekerley) (*, records not included in present checklist; see Material and Methods).

\begin{tabular}{|c|c|c|}
\hline Species & Specimens & Photographic records \\
\hline Akodon gr. cursor* ${ }^{*}$ & $\begin{array}{l}\text { AMNH 134495-134498-134499-134829-134830-134837- } \\
134856-134859, \text { MN 5177-5178-5180-4325-4368 } \\
\text { (CARMIGNOTTO, 2004 - see the comments of the author on } \\
\text { the impossibility of using caryotipe to discriminate species } \\
\text { from these vouchers). }\end{array}$ & \\
\hline Akodon montensis & $\begin{array}{l}\text { UFMG } \\
\text { 2682-2714, UFMG 2715 (CARMIGNOTTO, 2004); UFSM } 09 \\
\text { (CÁCERES et al., 2007a); UFMG } 2682 \text { (CÁCERES et al., 2008). }\end{array}$ & MCPAPI 386 \\
\hline Akodon sp.* & APC 975985996997 (CARMIGNOTTO, 2004). & \\
\hline Akodon toba & $\begin{array}{l}\text { USNM 390251-390252-390160-390162, CEUC } 58 \\
\text { (CARMIGNOTTO, 2004); UFSM 269, USNM 390251 (CÁCERES } \\
\text { et al., 2008); UFSM 258-269 (Godor et al., 2010a). }\end{array}$ & \\
\hline Alouatta caraya & $\begin{array}{l}\text { MN 4813, MZUSP 778-3364-3365-3769-19033-19034- } \\
\text { 5891-5892, (GREGORIN, 2006); MN 4794-4813-19176, } \\
\text { MZUSP 3769 (CÁCERES et al., 2008); MCPAP 116-117- } \\
\text { 121-125-362-527. }\end{array}$ & MCPAPI 520 \\
\hline Aotus azarae & MN 9608, MZUSP 9608 (CÁCERES et al., 2008). & \\
\hline Blastocerus dichotomus & $\begin{array}{l}\text { MHNCI 4037-4077, MZUSP } 28867 \text { (CÁCERES et al., 2008); } \\
\text { MCPAP 014-017-018-030-031-196-499. }\end{array}$ & MCPAPI 471 \\
\hline Cabassous unicinctus & MN 4975 (CÁCERES et al., 2008) & MCPAPI 405-465 \\
\hline Cabassous tatouay & AMNH M-133384 & \\
\hline Callicebus cf. pallescens & $\begin{array}{l}\text { MN 3355-3356-3358-3359-3351 (AURICCHIO, 2005); } \\
\text { MZUSP 3356-3358 (CÁCERES et al., 2008); MCPAP 528. }\end{array}$ & $\begin{array}{c}\text { MCPAPI } 446 \text { (a,b,c, d)-447-448-449- } \\
\text { 450-454-457-458-459-460-462 }\end{array}$ \\
\hline $\begin{array}{l}\text { Callithrix penicillata } \\
\text { Callomy sp.* }\end{array}$ & UFSM 28 (CÁCERES et al., 2007a). & MCPAPI 502-503-504 \\
\hline
\end{tabular}


Tab. III. Cont.

\begin{tabular}{|c|c|c|}
\hline Species & Specimens & Photographic records \\
\hline Calomys aff. callidus & UFSM 109 (CÁCERES et al., 2008). & \\
\hline Calomys callosus & $\begin{array}{l}\text { APC 897-934-951-957-971, CN 700-763 (CARMIGNOTO, } \\
\text { 2004); UFSM 162-165 (GoDOI et al., 2010a); MCPAP } \\
\text { 232-343. }\end{array}$ & \\
\hline Caluromys lanatus & AMNH 133206 (CARMIGNOTTO, 2004). & MCPAPI 384 \\
\hline Caluromys philander & $\begin{array}{l}\text { AMNH 139815 (CARMIGNOTTO, 2004); UFSM } 234 \text { (CÁ́CERES } \\
\text { et al., 2008). }\end{array}$ & MCPAPI 425 \\
\hline Cavia aperea & $\begin{array}{l}\text { FMNH 26638-26639-26870, MZUSP 4292-4293, MN 4476- } \\
\text { 4481 (CARMIGNOTTO, 2004); FMNH 26638, MN 4476, } \\
\text { MZUSP } 4292 \text { (CÁCERES et al., 2008); MCPAP } 325 .\end{array}$ & \\
\hline Cavia fulgida & $\begin{array}{l}\text { MZUSP } 28757 \text { (CARMIGNOTTO, 2004); MZUSP } 28757 \\
\text { (CÁCERES et al., 2008). }\end{array}$ & \\
\hline Cerdocyon thous & $\begin{array}{l}\text { MN 4908, MN 25602, MZUSP } 3769 \text { (CÁCERES, 2008); } \\
\text { MCPAP 103-106-135-136-140-145-302-321. }\end{array}$ & MCPAPI 392 \\
\hline Cerradomys maracajuensis & $\begin{array}{l}\text { MN 4409-4410-5207-34199, MN 44178, MZUSP } \\
28766 \text { (CARMIGNOTTO, 2004 - citado como Oryzomys } \\
\text { maracajuensis); MN 44178, MZUSP 28766, UFSM } 088 \\
\text { (CÁCERES et al., 2008). }\end{array}$ & \\
\hline Cerradomys scotti & $\begin{array}{l}\text { OMNH 19655, APC 885-887, MN } 4414 \text { (CARMIGNOTTO; } \\
\text { 2004; citado como Oryzomys scottii); UFSM 02-03-04-08-25 } \\
\text { (CÁCERES et al., 2007a); MN 4414, OMNH 19655, UFSM } \\
\text { 025-360 (CÁCERES } \text { et al., 2008); MCPAP 226-228. }\end{array}$ & \\
\hline Chironectes minimus & UFSM 031 (CÁCERES et al., 2008). & MCPAPI 467 \\
\hline Chrysocyon brachyurus & UFSM 081 (CÁCERES et al., 2008). & MCPAPI 368-396-466-484-485-517-518 \\
\hline Clyomys laticeps & $\begin{array}{l}\text { UFMG 2346- 2350, MN 24156-24158-31565, MN } 24159 \\
\text { (CARMIGNOTTO, 2004); MN 24156-63945, UFMG } 2346 \\
\text { (CÁCERES et al., 2008); MCPAP 188-207-213-216-278- } \\
\text { 294-313-342. }\end{array}$ & \\
\hline Coendou prehensilis & MN 3635, MZUSP 1859 (CÁCERES et al., 2008); MCPAP 234. & \\
\hline Conepatus chinga & AMNH 133946 (DraGOO et al., 2003). & \\
\hline Conepatus semistriatus & & MCPAPI 515 (a,b,c) \\
\hline Cryptonanus agricolai & UFSM 089-477 (CÁCERES et al., 2008). & MCPAPI 385-389-404 \\
\hline Cryptonanus chacoensis & $\begin{array}{l}\text { UFSM } 267 \text { (CÁCERES et al., 2008); MCPAP 220-341-346- } \\
355 .\end{array}$ & \\
\hline Cuniculus paca & MN 4871 (CÁCERES et al., 2008). & MCPAPI 481 \\
\hline Dasyprocta azarae & $\begin{array}{l}\text { MN 4968, MZUSP } 5896 \text { (CÁCERES et al., 2008); MCPAP } \\
\text { 112-113-114. }\end{array}$ & \\
\hline Dasypus novencinctus & $\begin{array}{l}\text { MHNCI 5660, MZUSP } 28768 \text { (CÁCERES et al., 2008); } \\
\text { MCPAP } 131 .\end{array}$ & MCPPI 369 \\
\hline Dasypus septemcinctus & & MCPAPI 541 (a, b, c, d, e, f) \\
\hline Didelphis albiventris & $\begin{array}{l}\text { MZUSP 3779-28753-28755-28803, MN 1187-4486-4487- } \\
\text { 4493-4497-4498-4766-4900-46898, AMNH 132988, UFMG } \\
\text { 2560-2558-2559-2561-2562 (CARMIGNOTTO, 2004); MN } \\
\text { 4486, MZUSP 3779-28753, UFMG 2558, UFSM } 045 \\
\text { (CÁCERES et al., 2008); MCPAP 219-285-297. }\end{array}$ & MCPAPI 393 \\
\hline Didelphis aurita & AMNH 133036 (CARMignotto 2004, CÁCERes et al., 2008). & \\
\hline Eira barbara & $\begin{array}{l}\text { MN 3110-5163, MZUSP } 3375 \text { (CÁCERES et al., 2008); } \\
\text { MCPAP 118-165-301. }\end{array}$ & MCPAPI 377-412-419-488-510 \\
\hline Euphractus sexcinctus & $\begin{array}{l}\text { MHNCI 5663, MN 4972, MZUSP } 28544 \text { (CÁCERES et al., } \\
\text { 2008); MCPAP 128-129-131-309. }\end{array}$ & \\
\hline Galictiss cuja & & MCPAPI 508 - 514(a,b,c) - $516(a, b)$ \\
\hline Galictis vittata & & MCPAPI 501 \\
\hline Gracilinanus agilis & $\begin{array}{l}\text { MZUSP 11800-11801-1712-342, PNPA 203, USNM } \\
\text { 390025, UFMG 2500-2533, APC 896, CN 70, MN 4465- } \\
\text { 4783-4787-4790, AMNH 133225-133227-133230-133231 } \\
\text { (CARMIGNOTTO, 2004); MN 4465, MZUSP 1712-11800, } \\
\text { UFMG 2500, UFSM 086, USNM 390025 (CÁCERES et al., } \\
\text { 2008); MCPAP 243-318. }\end{array}$ & MCPAPI 395- 406 \\
\hline Gracilinanus chacoensis & PNPA 205-207 (CARMIGNOTTO, 2004) & \\
\hline
\end{tabular}


Tab. III. Cont

\begin{tabular}{|c|c|c|}
\hline Species & Specimens & Photographic records \\
\hline Holochilus chacarius & $\begin{array}{l}\text { MN 1987, MZUSP 27430-3780 (CÁCERES et al. 2008, after } \\
\text { BRANDÃO \& NASCIMENTO, 2015). }\end{array}$ & \\
\hline Hydrochoerus hydrochaeris & $\begin{array}{l}\text { MHNCI 5658, MZUSP } 25358 \text { (CÁCERES et al., 2008); } \\
\text { MCPAP 077-087-092-094-179. }\end{array}$ & \\
\hline Hylaeamys megacephalus & $\begin{array}{l}\text { UFSM 11-30 (CÁCERES et al., 2007a); MZUSP 4303, UFMG } \\
\text { 2909, UFSM 016-033-061 (CÁCERES et al., 2008). }\end{array}$ & MCPAPI 383 \\
\hline Leopardus colocolo & $\begin{array}{l}\text { AMNH 133977-354 (GARCIA PEREA, 1994); MN 24904, } \\
\text { MZUSP } 7786 \text { (CÁCERES et al., 2008); video registrado } \\
\text { (SÁNCHEZ-Soto, 2007). }\end{array}$ & МCPAP 428-491-513 (a,b) \\
\hline Leopardus pardalis & $\begin{array}{l}\text { MN 68885, MZUSP 13673, UFSC 346-413 (Cáceres et al., } \\
\text { 2008); MCPAP 033-034-036-040-174-176-324. }\end{array}$ & MCPAPI 410- 495-512 \\
\hline Leopardus guttulus & $\begin{array}{l}\text { UEMS-Mundo Novo (CÁCERES et al., 2008); LBGM- UFRS } \\
\text { bLti-072. }\end{array}$ & \\
\hline Leopardus wiedii & МCPAP 168. & \\
\hline Lontra longicaudis & MN 3020 (Cáceres et al., 2008); MCPAP 312 & \\
\hline Lutreolina crassicaudata & $\begin{array}{l}\text { APC 655-657, MN 4780-4781-4784-20977, AMNH 133250- } \\
\text { 133251-133254-133255 (CARMIGNOTTO, 2004); MN } 20977 \text {, } \\
\text { UFSM } 326 \text { (CÁCERES et al., 2008). }\end{array}$ & MCPAPI 374-507(a,b) \\
\hline Lutreolina crassicaudata & $\begin{array}{l}\text { APC 655-657, MN 4780-4781-4784-20977, AMNH 133250- } \\
\text { 133251-133254-133255 (CARMIGNOTTO, 2004); MN 20977, } \\
\text { UFSM } 326 \text { (CÁCERES et al., 2008). }\end{array}$ & MCPAPI 374-507(a,b) \\
\hline Lycalopex vetulus & MN 4869-5151 (CÁCERES et al., 2008) & \\
\hline Marmosa (Micoureus) constantiae & $\begin{array}{l}\text { PNPA 102-313, APC 883-895-899-947-984 (CARMIGNOTTO, } \\
\text { 2004); UFSM 06-14 (CÁCERES et al., 2007a);UFSM 13-263- } \\
534 \text { (CÁCERES et al., 2008). }\end{array}$ & \\
\hline Marmosa murina & $\begin{array}{l}\text { APC } 658 \text {, MZUSP 1704-28756, UFMG } 2599 \text { (CARMIGNOTTO, } \\
\text { 2004); MZUSP 1704-28756, UFMG 2599, UFSM } 536 \\
\text { (CÁCERES et al., 2008) }\end{array}$ & MCPAPI $375-379$ \\
\hline Marmosops ocellatus & $\begin{array}{l}\text { PNPA 312-314-315-95-320-332-353-354-356 } \\
\text { (CARMIGNOTTO, 2004); MZUSP 32877, UFSM 213-268 } \\
\text { (CÁCERES et al., 2008). }\end{array}$ & \\
\hline Mazama americana & MZUSP 3735 (CÁCERES et al., 2008); MCPAP 014. & MCPAPI 387-390-463- 473-492 \\
\hline Mazama gouazoubira & $\begin{array}{l}\text { MZUSP } 3785 \text { (CÁCERES et al., 2008); MCPAP 001-003- } \\
\text { 007-011-012-015-029. }\end{array}$ & \\
\hline Mico melanurus & MN 3370, MZUSP 3370 (CÁCERES et al., 2008). & MCPAPI 464-497-521(a, b) \\
\hline Monodelphis domestica & $\begin{array}{l}\text { MZUSP 17424-1705-1707-1709-1711-3781, PNPA 96-307- } \\
\text { 309-311-93-94-101-114-115-117-123-124-305-319-330- } \\
\text { 352-355, USNM 390016, OMNH 19132, AMNH 37098, } \\
\text { APC 891-901-915-921-931-933-936-949-960-964-974- } \\
\text { 1000-1008 (CARMIGNOTTO, 2004); UFSM 07-10-24-29 } \\
\text { (CÁCERES et al., 2007a); AMNH 37098, MZUSP 1709- } \\
\text { 3781-17424, UFSM 040 (CÁCERES et al., 2008); MCPAP } \\
\text { 205-215-271-272-273-275-276-330-332-334-364. }\end{array}$ & MCPAPI 413 \\
\hline Monodelphis kunsi & $\begin{array}{l}\text { PNPA 286, APC 884-917-965-980-989-1007 (CARMIGNOTTO, } \\
\text { 2004); UFSM 167-265 (CÁCERES et al., 2008); ZUFMS-MA } \\
10001 \text { (HANNIBAL et al., 2012); MCPAP } 222 .\end{array}$ & MCPAPI 370- 414 \\
\hline Myrmecophaga tridactyla & $\begin{array}{l}\text { MZUSP 3727-7484-7485-7486-7487-7789-6893, MN 7053- } \\
24828 \text { (VAZ, 2003); MHNCI 4048, MN 5073, MZUSP } 7789 \\
\text { (CÁCERES et al., 2008); MCPAP 111-181-323. }\end{array}$ & MCPAPI 371 \\
\hline Nasua nasua & $\begin{array}{l}\text { MNHNCI 2551, MN 4895, MZUSP } 3366 \text { (CÁCERES et al., } \\
\text { 2008); MCPAP 104-105-107-127-134-144-147-300-320- } \\
\text { 347-357-359-361. }\end{array}$ & \\
\hline Necromys lasiurus & $\begin{array}{l}\text { PNPA 329-348-351, MZUSP 1701, FMNH 26640, AMNH } \\
\text { 37103-37104-134496, FMNH 26759, APC 926, CN 732-744- } \\
\text { 745-765-766 (CARMIGNOTTO, 2004); AMNH 37104, FMNH } \\
\text { 26640, MZUSP 1701-4301, OMNH 19132, UFSM 022 } \\
\text { (CÁCERES et al., 2008); UFSM 264-415 (Godor et al., 2010a). }\end{array}$ & $\begin{array}{l}\text { MCPAPI 397, MCPAPI } 400 \text {, } \\
\text { MCPAPI } 411 \text {, MCPAPI } 427\end{array}$ \\
\hline Nectomys rattus & $\begin{array}{l}\text { UFSM } 27 \text { (CÁCERES et al., 2007a); MN 46876, MZUSP } \\
\text { 6010, UFSM } 133 \text { (CÁCERES et al., 2008). }\end{array}$ & MCPAPI 380-399 \\
\hline
\end{tabular}


Tab. III. Cont.

\begin{tabular}{|c|c|c|}
\hline Species & Specimens & Photographic records \\
\hline Nectomys squamipes & $\begin{array}{l}\text { MN 4371-4381-34198, MN } 42685 \text { (CARMIGNOTTO, 2004); } \\
\text { UFSM 44, MZUSP } 28858 \text { (CÁCERES et al., 2008). }\end{array}$ & \\
\hline Oecomys bicolor & $\begin{array}{l}\text { MN 2520-2528-2544, FMNH 26806, MN 34200, AMNH } \\
\text { 134510-134511, UFMG 2818-2825-2817 (CARMIGNOTTO, } \\
\text { 2004); FMNH 26806, MN 2520-34200, UFMG 2817-2825, } \\
\text { UFSM 054-246-273 (CÁCERES et al., 2008); UFSM } 273 \\
\text { (GODOI } \text { et al., 2010a). }\end{array}$ & MCPAPI 373-398-420 \\
\hline Oecomys catherinae & $\begin{array}{l}\text { USNM 531278, UFMG, FMNH 26811, UFMG 2345-2827- } \\
\text { 2828-2829-2838, AC 2270-2271, APC 902-961-970-988- } \\
\text { 990-993-999 (CARMIGNOTTO, 2004). }\end{array}$ & \\
\hline Oecomys gr. catherinae* & $\begin{array}{l}\text { MZUSP } 28767 \text { (CARMIGNOTTO, 2004); MZUSP } 28767 \\
\text { (CÁCERES et al., 2008). }\end{array}$ & \\
\hline Oecomys mamorae & $\begin{array}{l}\text { JLP } 16961 \text { - voucher at UFMG (WEKSLER, 2003); CEUCCM } \\
\text { 211, FMNH 26811, MZUSP 2270, UFMG 2827, UFSM } \\
\text { 411, USNM 521278 (CÁCERES et al., 2008); MCPAP 229- } \\
\text { 239-247-268-269-329-331-333-363. }\end{array}$ & \\
\hline Oecomys paricola & CEUCN 198 (CÁCERES et al., 2008). & \\
\hline Oligoryzomys chacoensis & $\begin{array}{l}\text { FMNH 26805-26807-26810-26641, USNM 390124-390125, } \\
\text { APC 889-908-922-929, CN 758 (CARMIGNOTTO, 2004); } \\
\text { FMNH 26641, UFSM 168-271, USMN } 390125 \text { (CÁCERES } \\
\text { et al., 2008); UFSM 174-271 (Godol et al., 2010a). }\end{array}$ & \\
\hline Oligoryzomys fornesi & $\begin{array}{l}\text { OMNH 19657-19661-19660-19663, FMNH 26642, APC } \\
\text { 907-966-981, CN 747 (CARMIGNOTTO, 2004); OMNH 19657, } \\
\text { UFSM 020-242-272-367-378 (CÁCERES et al., 2008). }\end{array}$ & MCPAPI 403-408 \\
\hline Oligoryzomys nigripes & $\begin{array}{l}\text { MZUSP 25869, APC 890-903-906-909-913-923-927-928- } \\
\text { 945-946-948-958-959-967-969-979-1003-1004-1006, CN } \\
\text { 699-746-764, MN 4301-4303-4306-5219, AMNH 134541- } \\
\text { 134546-134551, UFMG 2760-2763 (CARMIGNOTTO, 2004); } \\
\text { UFSM 01 (CÁCERES et al., 2007): MN 5219, MZUSP 25869, } \\
\text { UFMG 2760, UFSM 001-021-278-486 (CÁCERES et al., } \\
\text { 2008); UFSM 278-353 (GoDOl et al., 2010a). }\end{array}$ & MCPAPI 394 \\
\hline Oryzomys (Euryoryzomys) nitidus & $\begin{array}{l}\text { FMNH 26786, USNM 390109-390110 (CARMIGNOTTO, } \\
\text { 2004); FMNH 26786, UFSM 260-261, USNM } 390110 \\
\text { (CÁCERES et al., 2008). }\end{array}$ & \\
\hline Oryzomys megacephalus & $\begin{array}{l}\text { MZUSP 1700-4303, APC 898-916-925-937-939-941- } \\
\text { 943-953-955-963-973-977-978-982-991-992-998-1005, } \\
\text { CN 743, UFMG 2909-2913-2924 (CARMIGNOTTO, 2004); } \\
\text { MCPAP 242. }\end{array}$ & \\
\hline Oxymycterus delator & & MCPAPI $519(\mathrm{a}, \mathrm{b}, \mathrm{c}, \mathrm{d}, \mathrm{e})$ \\
\hline Ozotoceros bezoarticus & $\begin{array}{l}\text { MZUSP } 01920 \text { (CÁCEREs et al., 2008); MCPAP 020-021- } \\
\text { 022-023-025-032-162. }\end{array}$ & MCPAPI 422 \\
\hline Panthera onca & $\begin{array}{l}\text { MHNCI 4384, MN 24859, MZUSP 9018, UFSC } 3105 \\
\text { (CÁCERES et al., 2008); MCPAP 045-046-047-048-049- } \\
\text { 306-530. }\end{array}$ & MCPAPI 444-445-451-468-472-478-487-496-511 \\
\hline Pecari tajacu & $\begin{array}{l}\text { MN 3826, MZUSP } 3342 \text { (CÁCERES } \text { et al., 2008); MCPAP } \\
\text { 051-052- 053-068-070-153-161-166-311 }\end{array}$ & MCPAPI 381-409 \\
\hline Phillander opossum & $\begin{array}{l}\text { AMNH 37063, UFMG 2662-2665, MN 29949, MZUSP } 8306 \\
\text { (CARMIGNOTTO, 2004); AMNH 37063, MN 29949, MZUSP } \\
\text { 8306, UFMG } 2662 \text { (CÁCERES et al., 2008). }\end{array}$ & \\
\hline Priodontes maximus & MN 1323 (VAZ, 2003); MCPAP 148-149. & MCPAPI 415-416-475-477-480-483-486-490 \\
\hline Procyon cancrivorus & МСРАР 120-123-126-164-172-173-180 & MCPAPI 388 \\
\hline Proechimys gr. goeldii* & $\begin{array}{l}\text { FMNH } 26732 \text { (CARMIGNOTTO, 2004); FMNH } 26732 \\
\text { (CÁCERES et al., 2008). }\end{array}$ & \\
\hline Proechimys longicaudatus & $\begin{array}{l}\text { PNPA 104-321-322-357, AMNH 37085-37086 } \\
\text { (CARMIGNOTTO, 2004); AMNH 37085, UFSM 034-259 } \\
\text { (CÁCERES et al., 2008); UFSM 259-354 (Godol et al., 2010a). }\end{array}$ & \\
\hline
\end{tabular}


Tab. III. Cont.

\begin{tabular}{|c|c|c|}
\hline Species & Specimens & Photographic records \\
\hline Proechimys roberti & UFSM 282 (CÁCERES et al., 2008). & \\
\hline Pseudoryzomys simplex & APC 659 (CARMignotTo, 2004). & \\
\hline Pteronura brasiliensis & MN 67470, MZSP 5890 (CÁCERES et al., 2008); MCPAP 115. & MCPAPI 443 \\
\hline Puma concolor & $\begin{array}{l}\text { MZUSP 28868, UFSC } 322 \text { (CÁCERES et al., 2008); MCPAP } \\
\text { 035-037-039-044. }\end{array}$ & MCPAPI 376-391-407-418-426-489-494 \\
\hline Puma yagouaroundi & UFSM 331 (CÁCERES et al., 2008); MCPAP 299-358-365. & MCPAPI 474 \\
\hline Rhipidomys macrurus & $\begin{array}{l}\text { UFMG } 2945 \text { (CARMIGNOTTO, 2004); UFMG 2945-032-156 } \\
\text { (CÁCERES et al., 2008). }\end{array}$ & MCPAPI 401 \\
\hline Rhipidomys sp.* & MN 4297-4442-30018-30024 (CARMIGNOTTO, 2004). & \\
\hline Sapajus cay & $\begin{array}{l}\text { MZUSP } 377-5133 \text { (MENDES PONTES et al., 2006); MZUSP } \\
19680 \text { (CÁCERES et al., 2008); MCPAP } 124 .\end{array}$ & MCPAPI 382 \\
\hline Speothos venaticus & MCPAP 119-322. & MCPAPI 498 \\
\hline Sylvilagus brasiliensis & MN 4774, UFSM 498 (CÁCERES et al., 2008); MCPAP 122. & MCPAPI 479-493 \\
\hline Tamandua tetradactyla & $\begin{array}{l}\text { MN 5056, MZUSP 20000, UFSC } 900 \text { (CÁCERES et al., 2008); } \\
\text { MCPAP 150-151-178-360. }\end{array}$ & MCPAPI 402 \\
\hline Tapirus terrestris & MZUSP 3727 (CÁCERES et al., 2008); MCPAP 066-067-191. & MCPAPI 378 \\
\hline Tayassu pecari & $\begin{array}{l}\text { UFSM } 334 \text { (CÁCERES et al., 2008); MCPAP 152-154-159- } \\
\text { 160-171-182-308. }\end{array}$ & MCPAPI 421-423 \\
\hline Thrichomys fosteri & $\begin{array}{l}\text { MZUSP 2673-26732-25868-25867-7499, PNPA 87-88-310- } \\
\text { 331-91-92-125-304-306, UFMG 3008, MN 6228-6229, APC } \\
\text { 888-892-894-900-914-918-920-924-935-938-940-944-954- } \\
\text { 956-962-972-976-983-986-987-994-1001-1002, MN 46896 } \\
\text { (CARMIGNOTTO, 2004); UFSM 15-26 (CÁCERES et al., 2007a); } \\
\text { MN 6228, MZUSP 7499-26731, UFMG 3008, UFSM 161 } \\
\text { (CÁCERES et al., 2008); MCPAP 184-190-197-208-236-250- } \\
\text { 259-265-287-315-345-354; CRB 553, LBCE 1920-1903- } \\
\text { 1960, MVZ 197572-197573 (NASCIMENTO et al., 2013). }\end{array}$ & \\
\hline Thylamys macrurus & $\begin{array}{l}\text { MZUSP 3782, APC 932-950-952-32097, NC 35-05 } \\
\text { (CARMIGNOTTO, 2004); MZUSP 3782-32094-3296-32097, } \\
\text { NC 05-35 (CARMIGNOTTO \& MONFORT, 2006); UFSM 35- } \\
\text { 05 (CÁCERES et al., 2007a), MZUSP 32097 (CÁCERES et } \\
\text { al., 2007a); MZUSP 3782 (CÁCERES et al., 2008); MCPAP } \\
\text { 225-231-326-328-335-336-337-338-339-340-356. }\end{array}$ & MCPAPI 424 \\
\hline Tolypeutes matacus & & MCPAPI 452-453-455-456-461-469-476-509 \\
\hline Urosciurus spadiceus & MN 1923, MZUSP 3352 (CÁCERES et al., 2008); MCPAP 430. & \\
\hline
\end{tabular}

threatened species recorded in the state: eight for Carnivora, three for Artiodactyla, two for Cingulata, two Chiroptera, one for Pilosa, and one for Didelphimorphia, from which eight species are Vulnerable, 10 are Near Threatened, and one Edangered (Tab. II). Some of these species are known to present large populations in the state (Tomas et al., 2011), especially in the Pantanal wetlands, $65 \%$ of which is located in Mato Grosso do Sul. For example, we may cite the Marsh deer (MourÃo et al., 2000), the Giant otter (TomAs et al., 2014, in press), the Jaguar (CAVAlCANTI et al., 2012; CAMILO, 2011), and the Pampas deer (MourÃo et al., 2000).

The previous checklist of mammals from the Mato Grosso do Sul reports 151 species, including 61 bat species (CÁCERES et al., 2008). In comparison, the present list represents an increase in the number of 15 species with primary records for the state, even considering that we avoided the inclusion of grouped specimens, interview data, non-confirmed or cataloged records, and non-native species. Although we attempted to produce a conservative checklist, we maintained few taxa that are still in need of taxonomic evaluation, such as Callicebus cf. pallescens and Callomys aff. callidus. It is evident also that Dasyprocta, Akodon, Rhipidomys, and Callomys deserve detailed taxonomic studies, and that scientific, regional mammal collections should be implemented to better document the species from Mato Grosso do Sul. Finally, it is clear that inventories at specific regions in the state are urgent, such as in the Chaco of the southwestern region, in the southern region previously covered by the Atlantic forest, and in the northeastern region near the border with Goiás and Mato Grosso states. Beyond the list of species, data on species occurrence are also required, as distribution maps are not available, what difficult the evaluation of the effectiveness of protected areas in conserving the species diversity, as 
Tab. IV. Specimens considered in the elaboration of the checklist of Chiroptera of the Mato Grosso do Sul State, Brazil. The specimens examined by other authors are followed by the reference to the correspondent publication. The taxons follow an alphabetical order, independent of their higher level taxonomic classification (Subfamily, Family, Order). The collections included are: MCPAP: Coleção de Referencia de Mamíferos da Embrapa Pantanal; MCPAPI: Coleção de Imagens de Referência de Mamíferos da Embrapa Pantanal; ZUFMS: Coleção Zoológica da Universidade Federal de Mato Grosso do Sul; UNIDERP - Coleção do Laboratório de Quiróteros da Universidade para o Desenvolvimento do Estado e da Região do Pantanal/ Anhanguera; UFSM: Coleção de Mamíferos da Universidade Federal de Santa Maria.

\begin{tabular}{|c|c|}
\hline Species & Specimens \\
\hline Anoura caudifer & $\begin{array}{l}\text { ZUFMS 1170, 1180, } 1291 \text { (BordignON, 2006); ZUFMS } 230 \text { (CAMARGO et al., 2009); ZUFMS } 453 \text { (FERNANDES, } \\
\text { 2009); ZUFMS } 500 \text { (FERREIRA et al., 2010); ZUFMS 293, } 292 \text { (CUNHA et al., 2011); ZUFMS 188, } 192 \text { (ERICKSON } \\
\text { et al., 2011). }\end{array}$ \\
\hline Anoura geoffroyi & ZUFMS 0151, 0368, 0454; ZUFMS 0292, 0293 (CUNHA et al., 2011); ZUFMS 454 (FERnANDES, 2009). \\
\hline Artibeus cinereus & ZUFMS 0389 (CUNHA et al., 2011); ZUFMS 0360. \\
\hline Artibeus fimbriatus & UFSM 541 (CÁCERES et al., 2008). \\
\hline Artibeus lituratus & $\begin{array}{l}\text { ZUFMS 0577; ZUFMS 1145, 1161, 1191, 1232, 1252, } 1300 \text { (BordiGNON, 2006); ZUFMS 913, } 1064 \text { (BordiGNON } \\
\text { \& FrANÇA, 2009); ZUFMS } 316 \text { (CUNHA et al., 2009); ZUFMS 2070, } 2120 \text { (LONGO, 2009); ZUFMS } 507 \\
\text { (FERREIRA, 2010). }\end{array}$ \\
\hline Artibeus obscurus & ZUFMS 715, 717 (BORDIGNON \& SANTOS, 2010). \\
\hline Artibeus planirostris & $\begin{array}{l}\text { ZUFMS (0179, 0371, 0372); ZUFMS 1242, } 1295 \text { (BordiGNON, 2006); ZUFMS 910, } 1074 \text { (BordiGNON \& } \\
\text { FrANÇA, 2009); ZUFMS } 482 \text { (CAMARGO et al., 2009); ZUFMS 323, } 328 \text { (CUNHA et al., 2009); ZUFMS 444, } 452 \\
\text { (FERNANDES, 2009); ZUFMS } 508 \text { (FerReIRA et al., 2010). }\end{array}$ \\
\hline Carollia perspicillata & $\begin{array}{l}\text { ZUFMS 0258; ZUFMS 1157, 1160, 1253, } 1298 \text { (BORDIGNON, 2006); ZUFMS 916, } 1040 \text { (BoRdiGNON \& FrANÇA, } \\
\text { 2009); ZUFMS 218, } 222 \text { (CAMARGO et al., 2009); ZUFMS } 313 \text { (CUNHA et al., 2009); ZUFMS 455, } 459 \text { (FERNANDEs, } \\
\text { 2009); ZUFMS } 497 \text { (FERREIRA et al., 2010); ZUFMS } 521 \text { (CUNHA et al., 2011). }\end{array}$ \\
\hline Chiroderma doriae & ZUFMS 0258; ZUFMS 912, 1058, 1069 (BordignON \& FranÇA, 2009); ZUFMS 493 (FErreira et al., 2010). \\
\hline Chiroderma villosum & ZUFMS 0158, 0159, 0208, 0209, 0505; ZUFMS 492 (FERREIRA et al., 2010). \\
\hline Chrotopteus auritus & ZUFMS 0109, 0354; ZUFMS 1194 (BORDIGNON, 2006); ZUFMS 254, 255 (CAMARGO et al., 2009). \\
\hline Cynomops abrasus & ZUFMS 0377; ZUFMS 220 (CAMARGO et al., 2009). \\
\hline Cynomops planirostris & ZUFMS 0162; ZUFMS 1163, 1209 (BoRDIGNON, 2006). \\
\hline Desmodus rotundus & $\begin{array}{l}\text { ZUFMS 0115, 0121, 0340, 0364; ZUFMS } 339 \text { (CAMARGO et al., 2009); ZUFMS } 314 \text { (CUNHA et al., 2009); } \\
\text { ZUFMS } 86 \text { (ERICKSON et al., 2011). }\end{array}$ \\
\hline Diaemus youngii & ZUFMS 0078, 0164, 0165. \\
\hline Eptesicus brasiliensis & ZUFMS 0160; UFSM 390 (CÁCERES et al., 2008). \\
\hline Eptesicus furinalis & ZUFMS 525. \\
\hline Eumops auripendulus & ZUFMS 0146. \\
\hline Eumops bonariensis & ZUFMS 1240 (BORDIGNON, 2006). \\
\hline Eumops dabbenei & ZUFMS 1319 (FisCHER et al., 2015) \\
\hline Eumops glaucinus & ZUFMS 0145, 0298; ZUFMS 1276 (BORDIGNON, 2006). \\
\hline Eumops patagonicus & ZUFMS 718 (BORDIGNON et al., 2011). \\
\hline Eumops perotis & ZUFMS 0045. \\
\hline Glossophaga soricina & $\begin{array}{l}\text { ZUFMS 0283, 0344, 0366, 0367, 0369; ZUFMS 1181, 1255, 1250, } 1282 \text { (BordiGNON, 2006); ZUFMS 920, 1088, } \\
1124 \text { (BordigNON \& FrANÇA, 2009); ZUFMS 248. } 312 \text { (CUNHA et al., 2009); ZUFMS } 499 \text { (FERREIRA et al., 2010). }\end{array}$ \\
\hline Lasiurus blossevillii & ZUFMS 0134, 0135, 0171, 0252; UNIDERP 2043 (ALHO et al., 2011). \\
\hline Lasiurus cinereus & UNIDERP 78 (ALHO et al., 2011). \\
\hline Lasiurus ega & ZUFMS 0138, 0176, 0253; ZUFMS 1296 (BORDIGNON, 2006). \\
\hline Lionycteris spurrelli & ZUFMS 1288 (BORDIGNON, 2006). \\
\hline Lonchophylla dekeyseri & ZUFMS 522, 523 (CUNHA et al., 2011). \\
\hline Lonchophylla mordax & ZUFMS 1179 (BORDIGNON, 2006). \\
\hline Lonchorhina aurita & ZUFMS 1287 (BORDIGNON, 2006). \\
\hline Lophostoma brasiliense & ZUFMS 0113, 0318, 0357; ZUFMS 1286 (BORDIGNON, 2006). \\
\hline Lophostoma silvicolum & ZUFMS 0110, 0181, 0356; ZUFMS 1159 (BORDIGNON, 2006); ZUFMS 1121 (BORDIGNON \& FrANÇA, 2009). \\
\hline Macrophyllum macrophyllum & ZUFMS 0072; ZUFMS 152 (CAMARGO et al., 2009). \\
\hline Micronycteris megalotis & ZUFMS 0347; ZUFMS 153 (ERCKSON et al., 2011). \\
\hline Micronycteris minuta & UNIDERP 117 (ALHO et al., 2011). \\
\hline Micronycteris sanborni & ZUFMS 0161 (SANTOS et al., 2011). \\
\hline Mimon bennettii & ZUFMS 441 (FERNANDES, 2009). \\
\hline Mimon crenulatum & ZUFMS 0108 (CAMARGO \& FISCHER, 2005). \\
\hline Molossops temminckii & $\begin{array}{l}\text { ZUFMS 0147; ZUFMS } 1279 \text { (BordiGNON, 2006); ZUFMS } 291 \text { (CUNHA et al., 2009); ZUFMS 494, } 495 \text { (FERREIRA } \\
\text { et al., 2010); ZUFMS } 294 \text { (CUNHA et al., 2011). }\end{array}$ \\
\hline Molossus molossus & ZUFMS 0271; ZUFMS 1275 (BordignON, 2006); ZUFMS 219 (CAMARGO et al., 2009). \\
\hline Molossus pretiosus & ZUFMS 682; UNIDERP 394 (ALHo et al., 2011). \\
\hline Molossus rufus & ZUFMS 09, 011 (CACERES et al., 2008). \\
\hline Myotis albescens & ZUFMS 0141, 0170; UNIDERP 227. \\
\hline Myotis nigricans & $\begin{array}{l}\text { ZUFMS 0133, 0137, 0172, 0175, 0203, 0204, 0283, 0378, 0379, 0381; ZUFMS } 1156 \text { (BordiGNON, 2006); ZUFMS } \\
\text { 213, } 215 \text { (CAMARGO et al., 2009); ZUFMS } 498 \text { (FERREIRA et al., 2010); UNIDERP } 1616 .\end{array}$ \\
\hline Myotis riparius & ZUFMS 0140; UNIDERP 1516. \\
\hline
\end{tabular}


Tab. IV. Cont

\begin{tabular}{|c|c|}
\hline Species & Specimens \\
\hline Myotis simus & ZUFMS 0006; UNIDERP 1498. \\
\hline Natalus macrourus & ZUFMS 0329, 0330, 0331; ZUFMS 144, 169 (CUNHA et al., 2009); ZUFMS 295 (CunHA et al., 2011). \\
\hline Noctilio albiventris & ZUFMS 0365; ZUFMS 0055, 0058 (CÁCERES et al., 2008). \\
\hline Noctilio leporinus & ZUFMS 0143 (CÁCERES et al., 2008). \\
\hline Nyctinomops laticaudatus & ZUFMS 0008, 0012, 0018, 0149, 0305, 0306, 0478. \\
\hline Nyctinomops macrotis & ZUFMS 0148; UNIDERP 3401 (ALHo et al., 2011). \\
\hline Peropteryx macrotis & ZUFMS 906 (BORDIGNON, 2005); UNIDERP 2175. \\
\hline Phyllosderma stenops & UNIDERP 547 (PULCHERO-LeITE et al., 1998). \\
\hline Phyllostomus discolor & ZUFMS 0105, 0155, 0355, 0468; ZUFMS 467 (CunHA et al., 2011). \\
\hline Phyllostomus elongatus & ZUFMS 1120 (BORDIGNON \& FRANÇA, 2009). \\
\hline Phyllostomus hastatus & $\begin{array}{l}\text { ZUFMS 0106, 0352, 0353; ZUFMS 1195 (BORDIGNON, 2006); ZUFMS } 1115 \text { (BORDIGNON \& FranÇA, 2009); } \\
\text { ZUFMS 300, } 301 \text { (CUNHA et al., 2009); ZUFMS } 491 \text { (FERREIRA et al., 2010). }\end{array}$ \\
\hline Platyrrhinus helleri & $\begin{array}{l}\text { ZUFMS 0158, 0361; ZUFMS 1173, } 1292 \text { (BORDIGNON, 2006); ZUFMS 442, } 443 \text { (FERNANDES, 2009); UNIDERP } \\
\text { 1328, 1923, 1936, 11668, 0058,0059, } 10345 \text { (ALHO et al., 2011). }\end{array}$ \\
\hline Platyrrhinus lineatus & $\begin{array}{l}\text { ZUFMS 0210, 0211, 0212, 0266, 0349, 0370; ZUFMS1149, } 1234 \text { (BordiGNON, 2006); ZUFMS 899, } 1099 \\
\text { (BordiGNON \& FranÇA, 2009); ZUFMS 223, } 228 \text { (CAMARGO et al., 2009); ZUFMS 503, } 506 \text { (FERreira et al., } \\
\text { 2010); UNIDERP 847, 863, 236, 745, 1329, 928, } 532 \text { (AlHo et al., 2011). }\end{array}$ \\
\hline Promops centralis & ZUFMS 00039 (CACERES et al., 2008). \\
\hline Promops nasutus & ZUFMS 000021 (CACERES et al., 2008). \\
\hline Pteronotus parnellii & ZUFMS 1289 (BORDIGNON, 2006). \\
\hline Pygoderma bilabiatum & ZUFMS 128 (ERICKSON et al., 2011). \\
\hline Rhynchonycteris naso & ZUFMS 0234, 0260, 0261. \\
\hline Sturnira lilium & ZUFMS 1241, 1274 (Bordignon, 2006); ZUFMS 131, 216, 217 (CAMARGO et al., 2009). \\
\hline Tadarida brasiliensis & ZUFMS 623 (SANTOS \& BoRdignON, 2011). \\
\hline Tonatia bidens & ZUFMS 237 (CUNHA et al., 2011); UNIDERP 941. \\
\hline Trachops cirrhosus & ZUFMS 524 (CuNHA et al., 2011). \\
\hline Uroderma bilobatum & ZUFMS 132. \\
\hline Uroderma magnirostrum & UNIDERP 2397. \\
\hline Vampyressa pusilla & ZUFMS 356. \\
\hline Vampyrodes caraccioli & ZUFMS 129. \\
\hline Vampyrum spectrum & M-CPAP 307 (SilveIra et al., 2011). \\
\hline
\end{tabular}

well as the elaboration of an endangered species list for the Mato Grosso do Sul state.

Main research groups. At Mato Grosso do Sul there are few institutions studying mammals. At Embrapa Pantanal, in Corumbá, most of the research has been focused on ecology of medium to large mammals, and small mammals, with little effort on taxonomy and distributions. At the Universidade Federal de Mato Grosso do Sul (UFMS) there are specialists on small mammals, primates and bats. Both institutions usually interact well, and partnership with several other institutions in Brazil increases the potential approaches to study the mammal fauna in the state. It is particularly relevant the role of post-graduation programs, such as the Ecology and Conservation Program, and the Animal Biology Program, at UFMS, in the establishment of partnership among institutions.

Main collections. The main in-state zoological collections are the Reference Vertebrate Collection of Embrapa Pantanal at Corumbá, the Zoological Collection of the Universidade Federal de Mato Grosso do Sul and the Zoological Collection of Laboratório de Quirópteros of Universidade para o Desenvolvimento do Estado e da Região do Pantanal (UNIDERP) at Campo Grande. However, these are relatively small collections, which do not comprehend all taxonomic groups among mammals. It is clear from the data used in this article that most of the specimens came from larger collection in Brazil and abroad. The main depositories of specimens from the state are Museu Nacional, Rio de Janeiro,
RJ; Museu de Zoologia da Universidade de São Paulo, São Paulo, SP; American Museum of Natural History, New York, USA; Field Museum of Natural History, Chicago, USA; the collections of the Laboratório de Biologia e Parasitologia de Mamíferos Reservatórios Silvestres - Fiocruz, Rio de Janeiro, RJ; Museum of Vertebrate Zoology, University of California at Bekerley, USA; and the Mammal Collection of the Universidade Federal de Santa Maria, Santa Maria, RS. Therefore, it is important to incentive the implementation of representative zoological collections by the local universities and research institutions to improve the knowledge and the data base for taxonomic studies and distribution assessments.

Main knowledge gaps. It is still necessary to develop studies on distributions of most of the mammalian species in the state, especially in regions where the man-made changes has eliminated the natural ecosystems, such as in the southern, central and eastern regions of the state. The southern region was once covered by the Atlantic forest, and it is presently highly developed with mechanized agriculture. Little is known about the mammal fauna in this area, especially along the border with Paraguay. It is possible that new records would be produced in the region, as several species known to occur in the other side of the frontier has not yet been found in Mato Grosso do Sul. In the central and eastern regions little has been done to increase the knowledge on the mammal fauna, and these areas are currently under expansion of forestry and biofuel projects (sugarcane plantations), as well as the intensification of 
cattle ranching and agriculture. Most of these areas are in the Cerrado ecosystem, but several types of wetlands exist in the headwaters. Hydroelectric developments are also a threat to these ecosystems as wetlands are usually located in lower terrain, which are the first to be eliminated together with its terrestrial mammalian fauna. The southwestern region, influenced by the Paraguayan Chaco, requires sound inventories as some species may be restricted in Brazil to this relatively small area. There is still a need for specific studies on taxonomy and distribution of some taxa, such as Oligoryzomys, Callomys, and Callicebus. The role of protected areas in conserving representative mammalian faunas in the state is still in need of consistent evaluation, including estimation of population sizes and trends for the most sensitive or endangered species. The knowledge on mammalian ecological functions (e.g. predators, pollinators, seed dispersers, vector/host of diseases) have been well studied only for some particular species or sites, lacking a more general picture across species and regions. Other relevant research hiatus are related to population dynamics, genetic structure, landscape use, dispersal, and local evolutionary histories. Furthermore, the general focus of available studies is on biological patterns rather than on the process shaping them. The use of mammals as indicator species is also necessary for habitat recovery and impact evaluations. Finally, the Mato Grosso do Sul is still requiring an official list of endangered species and their habitats, in order to influence public policies to protect them.

Perspectives for the next 10 years. In the following decade the perspectives for mammals from Mato Grosso do Sul will depend on the development of a strategic approach to increase the knowledge on this taxonomic group, particularly if partnership among specialists and institutions is achieved. In this sense, the BIOTA-MS Program, focused on the biodiversity at the state, certainly will play an important role. The BIOTA-MS should incentive and coordinate inventories at priority regions in the state, as well as help to increase the institutional capacity to organize, maintain and make available information from zoological collections. Among priority areas, we may list the Chaco in the southwestern region, the wetlands, the southern region, the northeastern region, and the western region along the border with Bolivia. For the future, ongoing new research lines will provide knowledge on some identified gaps. For instance, research projects in progress, including Ph.D. thesis and Master dissertations, have increasingly focused important lines in population ecology, dispersal, genetics and landscape use. Large-scale biogeographical patterns and local community assembly processes are other research lines which have been recently launched, which tend to substantially improve the knowledge on Mato Grosso do Sul's bat fauna and other mammalian groups in the state. Also, it may be expected an increase of the knowledge on ecology, natural history, and distribution of mammal species, as post-graduation program has been established and consolidated in the state. However, it is still necessary to understand the impact of economic development on mammal species, with focus on the responses to habitat fragmentation and degradation, and on the abundance and distribution of their populations. These types of knowledge are fundamental to establish conservation priorities, such as the selection of areas to be protected, the recovering of endangered species populations and habitats, the elaboration of public policies for ecosystem services payment schedules, and the strategies to ensure wildlife conservation in private lands.

Acknowledgements. We are grateful to Fundação de Apoio ao Desenvolvimento do Ensino, Ciências e Tecnologia do Estado de Mato Grosso do Sul (Fundect) and Superintendência de Ciência e Tecnologia do Estado de Mato Grosso do Sul (Sucitec/MS), through the BIOTA-MS Program, for the invitation to participate in this special fascicle of the Iheringia, série Zoologia, as well as for their financial support for the publication; Atenise Pulchério-Leite, Janaína Casella, Ricardo Bocchese, and Thiago Bernardes Maccarini shared their records with us. We thank Marco Costacurta for sharing his photographic record of Dasypus sptemcinctus. NLC was supported by FUNDECT (Ph.D. fellowship 23/200.118/2011). MS was granted by CNPq (MSc. fellowship) and CAPES (Ph.D. fellowship). MAT was granted by the Fundect/CNPq fellowship linked to the BIOTA-MS Program. MNG was supported by FUNDECT/CNPq (DCR 32282/422/3208./3010/2014). GM and EF receive a CNPq Productivity fellowship (n. 308631/2011-0 and 311001/2012-2, respectively).

\section{REFERENCES}

Alho, C. J. R.; Fischer, E.; Oliveira-Pissini, L. F. \& Santos, C. F. 2011. Bat-species richness in the Pantanal floodplain and its surrounding uplands. Brazilian Journal of Biology 71:311-320.

Alho, C. J. R.; Lacher-Jr., T. E.; Campos, Z. M. S. \& Gonçalves, H. C. 1987. Mamíferos da Fazenda Nhumirim, sub-região de Nhecolândia, Pantanal do Mato Grosso do Sul. I - Levantamento preliminar de espécies. Revista Brasileira de Zoologia 4(2):151-164.

AlLen, J. A. 1891. On a collection of birds from Chapada, Mato Grosso, Brazil, made by Mr. Herbert H. Smith. Part I - Oscines. Bulletin of the American Museum of Natural History 5:107-158.

AlLEN, J. A. 1892. On a collection of birds from Chapada, Mato Grosso, Brazil, made by Mr. Herbert H. Smith. Part II - Tyrannidae. Bulletin of the American Museum of Natural History 4:331-350.

Allen, J. A. 1893. On a collection of birds from Chapada, Mato Grosso, Brazil, made by Mr. Herbert H. Smith. Part III - Pipridae to Rheidae. Bulletin of the American Museum of Natural History 5:107-158.

ALLEN, J. A. 1916. Mammals collected on the Roosevelt Brazilian Expedition, with field notes by Leo E. Miller. Bulletin of the American Museum of Natural History 35:559-610.

AuricCHIO, P. 2005. História evolutiva de Primates: Análise filogenética de Callicebus Thomas, 1903 (Primates - Pitheciidae-Callicebinae). Tese de Doutorado. São Paulo, Universidade de São Paulo.

Bordignon, M. O. 2005. Predação de morcegos por Chrotopterus auritus (Peters) (Mammalia, Chiroptera) no Pantanal de Mato Grosso do Sul, Brasil. Revista Brasileira de Zoologia 22:1207-1208.

Bordignon, M. O. 2006. Diversidade de morcegos (Mammalia, Chiroptera) do Complexo Aporé-Sucuriú, Mato Grosso do Sul, Brasil. Revista Brasileira de Zoologia 23:1002-1009.

Bordignon, M. O.; Cáceres, N. C.; França, A. O.; Casella, J. \& Vargas, C. F. 2006. Inventário da mastofauna no Complexo Aporé-Sucuriú. In: Pagotto, T. C. S. \& Souza, P. R. eds. Biodiversidade do Complexo Aporé-Sucuriú. Subsídios à conservação e manejo do bioma Cerrado. Campo Grande, Editora da UFMS, 304p.

Bordignon, M. O. \& FrançA, A. O. 2009. Riqueza, diversidade e variação altitudinal em uma comunidade de morcegos filostomídeos (Mammalia: Chiroptera) no centro-oeste do Brasil. Chiroptera Neotropical 15:425433.

Bordignon, M. O. \& SAntos, T. M. R. 2010. Ampliação na distribuição de Artibeus obscurus (Schinz, 1822) no centro-oeste do Brasil. Chiroptera Neotropical 16:728-731. 
Bordignon, M. O.; Santos, T. M. R. \& Bernardi, I. P. 2011. Ocorrência de Eumops patagonicus Thomas, 1924 no limite dos biomas Chaco e Pantanal, Centro-Oeste do Brasil. Chiroptera Neotropical 17:953-956.

Brandẽo, M. V. \& NASCIMENTO, F. O. 2015. On the occurrence of Holochilus chacarius (Cricetidae: Sigmodontinae) in Brazil, with taxonomic notes on Holochilus species. Papéis Avulsos de Zoologia 55 (3): 47-67.

Cáceres, N. C.; Ferreira, V. L. \& Carmignotto, A. P. 2006. The occurrence of the mouse opossum Marmosops ocellatus (Marsupialia, Didelphidae) in western Brazil. Mammalian Biology 72(1):45-48.

Cáceres, N. C.; Bornschein, M. R.; Lopes, W. H. \& Percequillo, A. R. 2007a. Mammals of the Bodoquena Mountains, southwestern Brazil: an ecological and conservation analysis. Revista Brasileira de Zoologia 24(2):426-435.

Cáceres, N. C.; Napoli, R. P.; Lopes, W. H.; Casella, J. \& Gazeta, G. S. 2007b. Natural history of the marsupial Thylamys macrurus (Mammalia, Didelphidae) in fragments of savannah in southwestern Brazil. Journal of Natural History 41(29-32):1979-1988.

Cáceres, N. C.; Carmignotto, A. P.; Fischer, E. \& Santos, C. F. 2008. Mammals from Mato Grosso do Sul, Brazil. Check List 4(3):321-335.

Cáceres, N. C.; Godoi, M. N.; Hannibal, W. \& Ferreira, V. L. 2011. Effects of altitude and vegetation on small-mammal distribution in the Urucum Mountains, western Brazil. Journal of Tropical Ecology 27:279-287.

Cáceres, N.; Meloro, C.; Carotenuto, F.; Passaro, F.; Sponchiado, J.; Melo, G. L. \& RaiA, P. 2015. Ecogeographical variation in skull shape of capuchin monkeys. Journal of Biogeography 41: 501-512.

Camargo, G. \& Fischer, E. 2005. Primeiro registro do morcego Mimon crenulatum (Phyllostomidae) no Pantanal, sudoeste do Brasil. Biota Neotropica 5(1):1-4. Avaible at: <http://www.biotaneotropica.org.br/ $\mathrm{v} 5 \mathrm{n} 1 / \mathrm{pt} / \mathrm{abstract}$ ?short-communication+BN00705012005>.

Camargo, G.; Fischer, E.; Gonçalves, F.; Fernandes, G. \& Ferreira, S. 2009. Morcegos do Parque Nacional da Serra da Bodoquena, Mato Grosso do Sul, Brasil. Chiroptera Neotropical 15:417-424.

CAMILO, A. R. 2011. Distribuição atual de onça-parda (Puma concolor) e onça-pintada (Panthera onca) no Pantanal Brasileiro. Dissertação de Mestrado. Campo Grande, Universidade Federal de Mato Grosso do Sul.

Carmignotto, A. P. 2004. Pequenos mamíferos terrestres do bioma Cerrado: padrões faunísticos locais e regionais. Tese de Doutorado. São Paulo, Universidade São Paulo.

Carmignotto, A. P. \& Monfort, T. 2006. Taxonomy and distribution of the Brazilian species of Thylamys (Didelphimorphia: Didelphidae). Mammalia 2006:126-144

Cavalcanti, S. M. C.; Azevedo, F. C. C. De; Tomás, W. M.; Boulhosa, R. L. P. \& Crawshaw Jr., P. G. 2012. The status of the jaguar in the Pantanal. Cat News special Issue 7:29-34.

Cheida, C. C. \& Santos, L. B. 2010. Ordem Carnivora. In: Reis, N. R.; Peracchi, A. L.; Fregonezi, M. N. \& Rossaneis, B. K. eds. Mamíferos do Brasil Guia de Identificação. Rio de Janeiro, Technical Books Editora, p. 463-492.

Coelho, D. C. 2005. Ecologia e conservação da quiropterofauna no corredor Cerrado-Pantanal. Tese de Doutorado. Brasília, Universidade de Brasília.

Cope, E. D. 1889. On the Mammalia obtained by the naturalist exploring expedition to southern Brazil. American Naturalist 23:128-150.

Cunha, N. L.; Fischer, E.; Carvalho, L. F. A. C. \& Santos, C. F. 2009. Bats of Buraco das Araras reserve, southwestern Brazil. Biota Neotropica 9(4):189-195. Avaiable at: < http://www.biotaneotropica.org.br/v9n4/ pt/abstract?inventory+bn02909042009>

Cunha, N. L.; Fischer, E. \& Santos, C. F. 2011. Bat assemblage in savanna remnants of Sonora, central-western Brazil. Biota Neotropica 11(3):97-201. Avaiable at: $<$ http//www.biotaneotropica.org.br/v11n3/ pt/abstract?inventory+bn03311032011>

D’elía, G.J.; Hanson, D.; Mauldin, M. R.; Teta, P. \& Pardiñas, U. F. J. 2015. Molecular systematics of South American marsh rats of the genus Holochilus (Muroidea, Cricetidae, Sigmodontinae). Journal of Mammalogy 96(5):1081-1094.

De Vivo, M.; Carmignotto, A. P.; Gregorin, R.; Hingst-Zaher, E.; Iack-Ximenes, G. E.; Miretzki, M.; Percequillo, A. R.; Rollo Jr., M. M.; Rossi, R. V. \& TAdDEI, V. A. 2011. Checklist dos mamíferos do Estado de São Paulo, Brasil. Biota Neotropica 11(supl.1):111-131.

Dragoo, J. W.; HoneycutT, R. L. \& Schmidly, D. J. 2003. Taxonomic status of white-backed hog-nosed skunks, genus Conepatus (Carnivora: Mephitidae). Journal of Mammalogy 84(1):159-176.
Eriksson, A.; Graciolli, G. \& Fischer, E. 2011. Bat flies on phyllostomid hosts in the Cerrado region: component community, prevalence and intensity of parasitism. Memórias do Instituto Oswaldo Cruz 106:274278.

Ferreira, C. M. M.; Fischer, E. \& Pulchério-Leite, A. 2010. Fauna de morcegos em remanescentes urbanos de Cerrado em Campo Grande, Mato Grosso do Sul. Biota Neotropica 10(3):155160. Avaiable at: <http://www.biotaneotropica.org.br/v10n3/pt/ fullpaper?bn02910032010+pt>.

Fischer, E.; Santos, C. F.; Carvalho, L. F. A. C.; Camargo, G.; Cunha, N. L.; Silveira, M.; Bordignon, M. \& Silva, C. L. 2015. Bat fauna of Mato Grosso do Sul, southwestern Brazil. Biota Neotropica (Edição em Português. Online) 15: 1-17

Garbino, G. S. T. \& TeJedor, A. 2012. Natalus macrourus (Gervais, 1856) (Chiroptera: Natalidae) is a sênior synonym of Natalus espiritosantensis (Ruschi, 1951). Mammalia 4:1-4.

Garcia-PereA, R. 1994. The pampas cat group (genus Lynchailurus Svertzov, 1858 (Carnivora: Felidae)), a systematic and biogeographic review. American Museum Novitates 3096:1-35.

Gardner, A. L. \& Dagosto, M. 2008. Tribe Metachirini Reig, Kirsch, and Marshall, 1985. In: GARDNER, A. L. ed. Mammals of South America. Marsupials, Xenarthrans, Shrews, and Bats. vol. 1. London, The University of Chicago Press. 669p.

Godoi, M. N.; CunHA, N. L. \& CÁCERES N. C. 2010a. Efeito do gradiente floresta-cerrado campo sobre a comunidade de pequenos mamíferos do alto do maciço do Urucum, oeste do Brasil. Mastozoología Neotropical 17(2):263-277.

Godoi, M. N.; Teribele, R.; Bianchi, R.; Olifiers, N.; Concone, H. V. B. \& XAVIER Filho, N. L. 2010b. New records of pampas cat (Leopardus colocolo, Molina 1782) for Mato Grosso do Sul State, Brazil. Cat News 52:28-29.

Gregorin, R. 2006. Taxonomia e variação geográfica das espécies do gênero Alouatta Lacépède (Primates: Atelidae) no Brasil. Revista Brasileira de Zoologia 23(1):64-144.

Groves, C. P. 2001. Primate Taxonomy. Washington, Smithsonian Institution Press. 350p.

HanniBAL, W. 2014. Mammals of medium and large size from a fragmented seasonal forest landscape in Mato Grosso do Sul state, central-western Brazil. Check List 10(6): 1430-1434.

Hannibal, W.; Figueiredo, V. V.; Landgref Filho, P. \& Godoi, M. N. 2012. New records of Monodelphis kunsi (Didelphimorphia, Didelphidae) from Brazil. Mastozoología Neotropical 19:317-320.

Hannibal, W. \& Godoi M. N. 2015. Non-volant mammals of the Maracaju Mountains, southwestern Brazil: Composition, richness and conservation. Revista Mexicana de Biodiversidad 86: 1-9.

Hershkovitz, P. 1990. Titis, New World monkeys of the genus Callicebus (Cebidae, Platyrrhini): A preliminary taxonomic review. Fieldiana Zoology, New Series 55:1-109.

Iack-Ximenez, G. E. 1999. Taxonomia das espécies brasileiras de Dasyprocta e Myoprocta (Rodentia, Dasyproctidae). Dissertação de Mestrado. São Paulo, Universidade de São Paulo.

IBAMA. 2003. Fauna ameaçada de extinção no Brasil. Avaiable at: $<\mathrm{http} / /$ www.mma.gov.br/biodiversidade/especies-ameaçadas-de-extinção/ fauna-ameaçada>

IUCN. 2012. "Initiatives Mammals". IUCN Red List of Threatened Species. Version 2012.2. IUCN. Retrieved 2014-07-10. Available at: $<$ http://www.iucnredlist.org/initiatives/mammals $>$.

Jan, C.; Dawson, D. A.; Altringham, J. D.; Burke, T. \& Butlin, R. K. 2012. Development of conserved microsatellite markers of high crossspecies utility in bat species (Vespertilionidae, Chiroptera, Mammalia). Molecular Ecology Resources 12:532-548

Lim, B. K.; Engstrom, M. D.; Lee, T. E.; Patton, J. C. \& Bickham, J. W. 2004. Molecular differentiation of large species of fruit-eating bats (Artibeus) and phylogenetic relationships based on the cytochrome b gene. Acta Chiropterologica 6:1-12.

Lynch Alfaro, J. W.; Boubli, J. P.; Olson, L. E.; Di Fiore, A.; Wilson, B.; Gutiérrez-Espeleta, G. A.; Chiou, K. L.; Schulte, M.; Neitzel, S.; Ross, V.; Schwochow, D.; NGuYen, M. T. T.; FARIAS, I.; JANSON, C. H. \& Alfaro, M. E. 2011. Explosive Pleistocene range expansion leads to widespread Amazonian sympatry between robust and gracile capuchin monkey. Journal of Biogeography 39:272-288. 
Mamede, S. B. \& Alho, C. J. R. 2006. Responses of wild mammals to seasonal shrinking and expansion of habitats due to flooding regime of the Pantanal, Brazil. Brazilian Journal of Biology 66(4):991-998.

Mendes Pontes, A. R.; Malta, A. \& Asfora, P. H. 2006.A new species of capuchin monkey, genus Cebus Erxleben (Cebidae, Primates): found at the very brink of extinction in the Pernambuco Endemism Centre. Zootaxa 1200:1-12.

Miller, L. 1915. Mammal collected by the Roosevelt Brazilian Expedition with field notes by Leo E. Miller. Bulletin of the American Museum of Natural History 35:559-610.

Miranda Ribeiro, A. 1914. Zoologia. Commisão de Linhas Telegráphicas Estratégicas de Matto-Grosso ao Amazonas. História Natural, Mamíferos 17:1-49.

Mourão, G. M.; Coutinho, M. E.; Mauro, R. A.; Tomás, W. M. \& Magnusson, W. 2002. Levantamento aéreos de espécies introduzidas no Pantanal: porco ferais (porco monteiro), gado bovino e búfalos. Corumbá, Embrapa Pantanal. Boletim de Pesquisa e Desenvolvimento 28:1-22.

Mourão, G. M.; Coutinho, M.; Mauro, R. A.; Campos, Z.; Tomás, W. \& Magnusson, W. 2000. Aerial surveys of caiman, marsh deer and pampas deer in the Pantanal Wetland of Brazil. Biological Conservation 92:175-183.

Myers, N.; Mittermeier, R. A.; Mittermeier, C. G.; Fonseca, G. A. B. \& KENT, J. 2000. Biodiversity hotspots for conservation priorities. Nature 403:853-858

Nascimento, F. F.; Lazar, A.; Menezes, A. N.; Durans, A. M.; Moreira, J. C.; Salazar-Bravo, J.; Andrea, P. S. D. \& Bonvicino, C. R. 2013. The Role of Historical Barriers in the Diversification Processes in Open Vegetation Formations during the Miocene/Pliocene Using an Ancient Rodent Lineage as a Model. Plos One 8(4):e6192.

OJASTI, O. 1990. Las comunidades de mamiferos en sabanas neotropicales. In: Sarmiento, G. ed. Las sabanas Americanas. Caracas, Fondo Editorial Acta Científica de Venezuela, p. 259-293.

Paglia, A. P.; Fonseca, G. A. B.; Rylands , A. B.; Herrmann, G.; Aguiar, L. M. S.; Chiarello, A. G.; Leite, Y. L. R.; Costa, L. P.; Siciliano, S.; Kierulff, M. C. M.; Mendes, S. L.; Tavares, V. C.; Mittermeier, R. A. \& Patton, J. L. 2012. Lista Anotada dos Mamíferos do Brasil/ Annotated Checklist of Brazilian Mammals. 2ed. Occasional Papers in Conservation Biology 6:1-76.

Pelzen, A. 1883. Brasilische Säugetiere. Resultate von Johann Natterer's Reise in den Jahren 1817 bis 1835 . Verhandlungen der ZoologischBotanischen Gesellschaft in Wiener Vienna 33:1-140.

Pulchério-Leite, A.; Meneghelli, M. \& Taddei, V. A. 1998. Morcegos (Chiroptera: Mammalia) dos pantanais de Aquidauana e da Nhecolândia, Mato Grosso do Sul. I. Diversidade de espécies. Ensaios e Ciências 2(2):167-174.

RamberG, L.; Hancock, P.; Llindholm, M.; Meyer, T.; Ringrose, S.; Silva, J.; VAn As, J. \& VANDERspot, C. 2006. Species diversity of the Okavango Delta, Botswana. Aquatic Sciences 68:310-337.

Reis, N. R.; Shibata, O. A.; Peracchi, A. L.; Pedro, W. A. \& Lima, I. P. 2011. Sobre os Mamíferos do Brasil. In: ReIs, N. R.; Peracchi, A. L.; Pedro, W. A. \& Lima, I. P. eds. Mamíferos do Brasil. Londrina, Second Edition, p. 23-29.

Rodrigues, F. H. G.; Silveira, L.; Jácomo, A. T. A.; Carmignotto, A. P.; Bezerra, A. M. R.; Coelho, D. C.; Garbogini, H.; Pagnozzi, J. \& Hass, A. 2002. Composição e caracterização da fauna de mamíferos do Parque Nacional das Emas, Goiás, Brasil. Revista Brasileira de Zoologia 19(2):589-600.

Roosmalen, M. G. M.; Van Roosmalen, T. \& Mittermeier, R. A. 2002. A Taxonomic review of the titi monkeys, genus Callicebus Thomas, 1903, with the description of two species, Callicebusbernhardi and Callicebus stephennashi, from Brazilian Amazonia. Neotropical Primates 10(suppl.):1-52.

SÁNCHEZ-Soto, S. 2007. Nuevo registro de Oncifelis colocolo (Felidae) para el Pantanal de Brasil. Revista Mexicana de Biodiversidad 78:211-212.

Santos, C. F.; Nogueira, M.; Cunha, N. L.; Carvalho, L. F. A. C. \& FisCHER, E. 2010. Southernmost record of the Sanborn's big-eared bat, Micronycteris sanborni (Chiroptera, Phyllostomidae). Mammalia 74:457-460.

Santos, T. M. R. \& Bordignon, M. O. 2011. Primeiro registro de Tadarida brasiliensis (I. Geoffroy, 1824) para o Pantanal Brasileiro. Chiroptera Neotropical 17:832-835

SCHAller, G. B. 1983. Mammals and their biomass on a Brazilian ranch. Arquivos de Zoologia 31:1-36.

Silveira, M.; Munin, R. L.; Tomas, W. M.; Fischer, E.; Bordignon, M. \& SilveIRA, G. A. 2011. The distribution of the spectral bat, Vampyrum spectrum, reaches the southern Pantanal. Biota Neotropica 11(1):173176. Avaiable at: < http://www.biotaneotropica.org.br/v11n1/en/abstra ct?article+bn02511012011>

Teribele, R.; Concone, H. V. B.; Godoi, M. N.; Bianchi, R. C.; Santos, J. C. C.; Mauro, R. A.; Filho, N. L. X. \& Mello, A. V. 2012. New records for bush dog in Mato Grosso do Sul, Brazil. Canid News [on line]:1-4.Avaiable at: <http://www.canids.org/canidnews/15/ Bush dog MatoGrosso.pdf $>$.

Tomás, W. M.; Cáceres, N. C.; Fischer, E.; Mourão, G. \& Campos, Z. 2011. Mammals in the Pantanal wetland, Brazil. In: JUNK, W. J.; da Silva, C. J.; Nunes da Cunha, C. \& Wantzen, K. M. eds. The Pantanal. Ecology, biodiversity and sustainable management of a large neotropical seasonal wetland. Sofia-Moscow, Pensoft Publishers, p.563-595.

Tomás, W. M.; Camilo, A. R.; Campos, Z.; Chiaravallotti, R. M.; Lacerda, A. C. R.; Borges, P. A. L.; Medri, I. M.; Nunes, A. P.; Tomas, M. A.; Goulart, C. S.; Borghezan, H.; Lopes, V. A. \& Aragona, M. 2009. Ocorrência de Tatu-de-rabo-mole, Cabassous unicinctus (Cingulata, Dasypodidae) no Pantanal, Brasil. Boletim de Pesquisa e Desenvolvimento 87:1-19.

Tomás, W. M.; Camilo, A. R.; Ribas, C.; Leuchtenberger, C.; Lima Borges, P.A.; Mourão, G. \& Pellegrin. L. A. 2014. Distribution and conservation status of giant otter (Pteronura brasiliensis) in the Pantanal wetland, Brazil. Latin American Journal of Aquatic Mammals (in press).

Tomás, W. M. \& MourÃo, G. M. 2007. Mastofauna de médio e grande portes. In: Relatório Executivo da Expedição Exploratória e Científica da Reserva Particular do Patrimônio Natural Engenheiro Eliezer Batista. Corumbá, Instituto Homem Pantaneiro, p. 121-134.

TRAVASSOS, L. 1940. I- Introdução. Relatório da terceira excursão à zona da estrada de ferro Noroeste do Brasil realizada em Fevereiro e Março de 1940. Memórias do Instituto Oswaldo Cruz 35:607-713.

Travassos, L.; Pinto, C. \& Muniz, J. 1927. Excursão scientifica ao Estado de Matto Grosso na Zona do Pantanal (margens dos rios S. Lourenço e Cuyabá) realizada em 1922. Memórias do Instituto Oswaldo Cruz 20:249-269.

Trigo, T. C.; Schneider, A.; De Oliveira, T. G.; Lehugeur, L. M.; Silveira, L.; Freitas, T. R. O. \& Eizirik, E. 2013. Molecular Data Reveal Complex Hybridization and a Cryptic Species of Neotropical Wild Cat. Current Biology 23: 2528-2533.

Vanzolini, P. E. 1993. As viagens de Johann Natterer no Brasil, 1817-1835. Papéis Avulsos de Zoologia 38(3):17-60.

VAZ, S. M. 2003. Lista de localidades de captura de xernatros sob ameaça de extinção no Brasil. Edentata 5:4-5.

VIEIRA, C. C. 1940. Algumas observações sobre a fauna da região de Salobra, estado de Mato Grosso. Memórias do Instituto Oswaldo Cruz 35:557-567.

VieIRA, C. C. 1955. Lista remissiva dos mamíferos do Brasil. Arquivos de Zoologia do Estado de São Paulo 8:341-474.

Weksler, M. 2003. Phylogeny of Neotropical oryzomyine rodents (Muridae: Sigmodontinae) based on the nuclear IRBP exon. Molecular Phylogenetics and Evolution 29:331-349.

Weksler, M.; Percequillo, A. R. \& Voss R. S. 2006. Ten new genera of oryzomyine rodents (Cricetidae: Sigmodontinae). American Museum Novitates 3537:1-29.

Wetzel, R. M. 1980. Revision of the naked-tailed armadillos, genus Cabassous McMurtrie. Annals of Carnegie Museum 49:323-357.

Wilson, D. E. \& ReEder, D. M. 2005. Mammal species of the world a taxonomic and geographic reference. 3ed. Baltimore, The John Hopkins University Press. 2.142p.

Yahnke, C. J.; Fox, I. G. \& Colman, F. 1998. Mammalian species richness in Paraguay: the effectiveness of National Parks in preserving biodiversity. Biological Conservation 84:263-268.

Yensen, E. \& TARIFA, T. 2003a. Galictis vitatta. Mammalian Species 727:1-8.

Yensen, E. \& TARIFA, T. 2003b. Galictis cuja. Mammalian Species 728:1-8. 